University of South Florida

DIGITAL COMMONS

Digital Commons @ University of

@ UNIVERSITY OF SOUTH FLORIDA

South Florida

\title{
Non-Redfield Carbon and Nitrogen Cycling in the Arctic: Effects of Ecosystem Structure and Dynamics
}

\author{
Kendra L. Daly \\ University of Tennessee, Knoxville, kdaly@marine.usf.edu \\ Douglas W. R. Wallace \\ Universitat Kiel \\ Walker O. Smith Jr. \\ Virginia Institute of Marine Science \\ Annelie Skoog \\ University of Connecticut \\ Rubén Lara \\ Zentrum fur Marine Tropenokologie
}

See next page for additional authors

Follow this and additional works at: https://digitalcommons.usf.edu/msc_facpub

Part of the Life Sciences Commons

\section{Scholar Commons Citation}

Daly, Kendra L.; Wallace, Douglas W. R.; Smith, Walker O. Jr.; Skoog, Annelie; Lara, Rubén; Gosselin, Michel; Falck, Eva; and Yager, Patrick L., "Non-Redfield Carbon and Nitrogen Cycling in the Arctic: Effects of Ecosystem Structure and Dynamics" (1999). Marine Science Faculty Publications. 840.

https://digitalcommons.usf.edu/msc_facpub/840

This Article is brought to you for free and open access by the College of Marine Science at Digital Commons @ University of South Florida. It has been accepted for inclusion in Marine Science Faculty Publications by an authorized administrator of Digital Commons @ University of South Florida. For more information, please contact digitalcommons@usf.edu. 


\section{Authors}

Kendra L. Daly, Douglas W. R. Wallace, Walker O. Smith Jr., Annelie Skoog, Rubén Lara, Michel Gosselin, Eva Falck, and Patrick L. Yager 


\title{
Non-Redfield carbon and nitrogen cycling in the Arctic: Effects of ecosystem structure and dynamics
}

\author{
Kendra L. Daly, ${ }^{1,2}$ Douglas W. R. Wallace, ${ }^{3}$ Walker O. Smith Jr., ${ }^{4}$ Annelie Skoog, ${ }^{5}$ \\ Rubén Lara, ${ }^{6}$ Michel Gosselin, ${ }^{7}$ Eva Falck, ${ }^{8}$ and Patricia L. Yager ${ }^{9}$
}

\begin{abstract}
The $\mathrm{C}: \mathrm{N}$ ratio is a critical parameter used in both global ocean carbon models and field studies to understand carbon and nutrient cycling as well as to estimate exported carbon from the euphotic zone. The so-called Redfield ratio ( $\mathrm{C}: \mathrm{N}=6.6$ by atoms) [Redfield et al., 1963] is widely used for such calculations. Here we present data from the NE Greenland continental shelf that show that most of the $\mathrm{C}: \mathrm{N}$ ratios for particulate (autotrophic and heterotrophic) and dissolved pools and rates of transformation among them exceed Redfield proportions from June to August, owing to species composition, size, and biological interactions. The ecosystem components that likely comprised sinking particles and had relatively high C:N ratios (geometric means) included (l) the particulate organic matter $(\mathrm{C}: \mathrm{N}=8.9)$ dominated by nutrient-deficient diatoms, resulting from low initial nitrate concentrations (approximately 4 $\mu M)$ in Arctic surface waters; (2) the dominant zooplankton, herbivorous copepods ( $\mathrm{C}: \mathrm{N}=$ 9.6), having lipid storage typical of Arctic copepods; and (3) copepod fecal pellets (C:N = 33.2). Relatively high dissolved organic carbon concentrations (median $105 \mu M$ ) were approximately 25 to $45 \mu M$ higher than reported for other systems and may be broadly characteristic of Arctic waters. A carbon-rich dissolved organic carbon pool also was generated during summer. Since the magnitude of carbon and nitrogen uncoupling in the surface mixed layer appeared to be greater than in other regions and occurred throughout the productive season, the C:N ratio of particulate organic matter may be a better conversion factor than the Redfield ratio to estimate carbon export for broad application in northern high-latitude systems.
\end{abstract}

\section{Introduction}

The role of the marine biosphere in the global carbon cycle is controversial and remains poorly constrained owing to uncertainties in the magnitude and natural variability of carbon export from the euphotic zone. There is also a lack of basic information about the various factors that govern the biological activity influencing the quantity and nature of carbon export [Longhurst, 1991; Siegenthaler and Sarmiento, 1993]. Biogeochemical dynamics in high-latitude systems, in par-

\footnotetext{
' Department of Ecology and Evolutionary Biology, University of Tennessee, Knoxville.

${ }^{2}$ Now at Division of Ocean Sciences, National Science Foundation, Arlington, Virginia.

${ }^{3}$ Institut für Meereskunde, Universitãt Kiel, Kiel, Germany.

${ }^{4}$ Virginia Institute of Marine Science, Gloucester Point.

${ }^{5}$ Department of Marine Science, University of Connecticut, Groton.

${ }^{6}$ Zentrum für Marine Tropenokologie, Bremen, Germany.

${ }^{7}$ Départment d'Océanographie, Université du Québec à Rimouski, Québec, Canada.

${ }^{8}$ Geophysical Institute, University of Bergen, Bergen, Norway.

${ }^{9}$ Department of Marine Science, University of Georgia, Athens.

Copyright 1999 by the American Geophysical Union.

Paper number 1998JC900071.

0148-0227/99/1998JC $900071 \$ 09.00$
}

ticular, are not well known, although there have been recent upward revisions of annual new production and carbon export [e.g., Walsh et al., 1989; Simith et al., 1991].

The Redfield ratio [Redfield et al., 1963] is a critical parameter used in both global ocean carbon models and field studies to understand carbon and nutrient cycling [e.g., Campbell and Aarup, 1992; Najjar et al., 1992; Hansell et al., 1993; Shaffer, 1996; Six and Maier-Reimer, 1996]. The Redfield ratio also is commonly used to estimate carbon export indirectly (see review by Jahnke [1990] and references therein) and is based on the assumption that the elemental composition of particulate organic matter produced and exported from the surface layer occurs in constant proportion. On average, the Redfield molar ratio is 6.6 and includes both phytoplankton and zooplankton. Nitrogen is thought to be the element that limits primary production in many regions of the ocean under steady state conditions and on an annual timescale. Under such conditions, the nitrate flux from deep water to the surface should equal the amount of organic nitrogen exported from the surface, and, by Redfield ratio conversion, the organic carbon that enters deep water can be calculated [ $\mathrm{Dug}$ dale and Goering, 1967; Eppley and Peterson, 1979]. Primary production resulting from nitrate uptake by phytoplankton is termed "new production," neglecting nitrogen fixation and allocthonous inputs, while production from ammonium or urea uptake is called "regenerated production." 
The stoichiometry and use of the Redfield ratio, however, are being debated. Although Redfield et al. [1963, p. 28] noted that the use of the ratios to evaluate nutrient-plankton interactions depended on "the assumption that the composition of the plankton is statistically constant," they also recognized that elemental ratios of phytoplankton and zooplankton varied seasonally and by location, as did a number of subsequent field and laboratory studies [e.g., Beers, 1966; Sakshaug and Holm-Hansen, 1977; Claustre et al., 1992]. Other reports supported the concept of invariant elemental ratios in particulate organic matter [e.g., Copin-Montegut and CopinMontegut, 1983; Chen et al., 1996]. In 1985, Takahashi et al. [1985] suggested an upward revision of the C:N ratio to 7.6 based on chemical data from isopycnal surfaces. More recently, Sambrotto et al. [1993] observed a net decrease in dissolved inorganic carbon (DIC) relative to nitrate during productive periods, which exceeded that predicted by Redfield proportions even though the elemental composition of particulate organic matter was similar to Redfield, and suggested that carbon export may be underestimated. Banse [1994] further pointed out that DIC and nitrate pools may not be coupled. Both reports agreed that heterotrophic processes and the dynamics of the dissolved organic pool are important to understanding nutrient cycling. These studies underscore the need to determine when and under what conditions surface carbon and nitrogen cycling become uncoupled relative to expected Redfield stoichiometry and to understand the processes that govern the relationship between carbon and nitrogen fluxes.

In 1993 we had the opportunity to study in detail the carbon and nitrogen dynamics of a high-latitude marine ecosystem. As part of the Northeast Water (NEW) Polynya program conducted on the northeastern continental shelf of Greenland, we measured inventories and rates related to dissolved inorganic carbon and nitrogen, dissolved and particulate organic carbon and nitrogen, primary productivity and new production, and the elemental composition, physiology, and egestion of the dominant zooplankton. The debate concerning the influence of plankton on biogeochemical cycles [e.g., Longhurst, 1991; Siegenthaler and Sarmiento, 1993; Banse, 1994] focused our attention on the role of species composition and function in elemental cycling and on the uncertainties associated with estimating new production, including the assumption of invariant Redfield elemental composition of biogenic matter.

\section{Materials and Methods}

\subsection{Study A rea}

The Northeast Water (NEW) Polynya was sampled in 1993, from May 22 to July 25 aboard the FS Polarstern and from July 25 to August 20 aboard the USCGC Polar Sea (Figure 1). Most of the results reported here were obtained on board the Polar Sea, except dissolved organic matter concentrations and urea uptake rates, which were measured from May to early July on the Polarstern, and copepod body CN and egestion rates, which were measured on both ships from May to August.

Polynyas are regions of open water that are surrounded by sea ice and are sites of elevated biological activity. The NEW
Polynya is a recurring feature that typically opens each year in May, reaches a maximum extent in August (approximately $10,000 \mathrm{~km}^{2}$ in 1993) [NEWATER Steering Committee, 1993], and closes rapidly in September. The physical characteristics of the region have been described by Budéus and Schneider [1995] and Johnson and Niebauer [1995]. An anticyclonic gyre over the Norske and Westwind troughs and Belgica Bank (Figure 1) is largely controlled by the bathymetry, which is a system of troughs up to $500 \mathrm{~m}$ deep with a central bank. In 1993 the polynya was located over the Norske and Westwind troughs, where the mean surface current velocity was about 10 $\mathrm{cm} \mathrm{s}^{-1}$ [Johnson and Niebauer, 1995]. Station locations (Polar Sea, number of stations $n=152$ ) were chosen in order to characterize a range of environmental conditions. A times series station at the northern end of the Norske Trough (Figure 1) also was occupied several times during the study period.

\subsection{Experimental Procedures}

Water samples were collected using 10-L Niskin bottles that had been fitted with Teflon-coated, stainless steel springs mounted on a rosette sampling system. Subsamples were taken for the analysis of dissolved and particulate concentrations. Total carbon dioxide $\left(\mathrm{TCO}_{2}\right)$ was analyzed by coulometric titration using a SOMMA system following the methods described by Johnson et al. [1993]. Dissolved oxygen and nutrients were analyzed using standard techniques (Winkler titrations and Technicon Autoanalyzer II [Wallace et al., 1995] ). Urea samples were frozen at sea and later analyzed using the urea-diacetyl monoxime method on an Alpkem autoanalyzer [Koroleff, 1983]. Dissolved organic carbon was analyzed by the high-temperature catalytic oxidation method [Anderson et al., 1994] and dissolved organic nitrogen by the persulfate wet oxidation method [Lara et al., 1993].

Particulate organic carbon (POC) and nitrogen (PON) samples were determined by filtering known volumes of seawater through combusted GF/F Whatman glass fiber filters. At some stations, particulate matter was size fractionated in order to assess resource partitioning and quality of food available to grazers. Samples were gravity filtered through Nitex screens and then gently backwashed onto a combusted GF/F filter. Blanks consisted of refiltered filtrate. Filters were analyzed in a shore-based laboratory on a Carlo-Erba model EA 1108 elemental autoanalyzer after high-temperature pyrolysis, using acetanilide as a standard. Chlorophyll $a$ fluorescence was measured immediately after collection on a calibrated Turner Designs model 10 fluorometer after sonification and extraction with $90 \%$ acetone. Primary productivity and nitrogen (nitrate, ammonium, and urea) uptake were measured using ${ }^{14} \mathrm{C}$ and ${ }^{15} \mathrm{~N}$-tracer techniques [Smith, 1995; W. O. Smith et al., 1997]. Samples were incubated on deck for approximately 24 hours under conditions that simulated the quantity and quality of in situ light and sea-surface temperatures.

Zooplankton were collected with a $1-\mathrm{m}$ ring net fitted with a $149-\mu \mathrm{m}$ mesh net and a non-filtering cod end. The net was towed vertically from $50 \mathrm{~m}$ to the surface at a slow sampling speed $\left(10 \mathrm{~m} \mathrm{~min}^{-1}\right)$ in order to minimize stress to the animals. Undamaged, active adult female Calanus hyperboreus, $C$. glacialis, and Metridia longa were sorted into experimental 


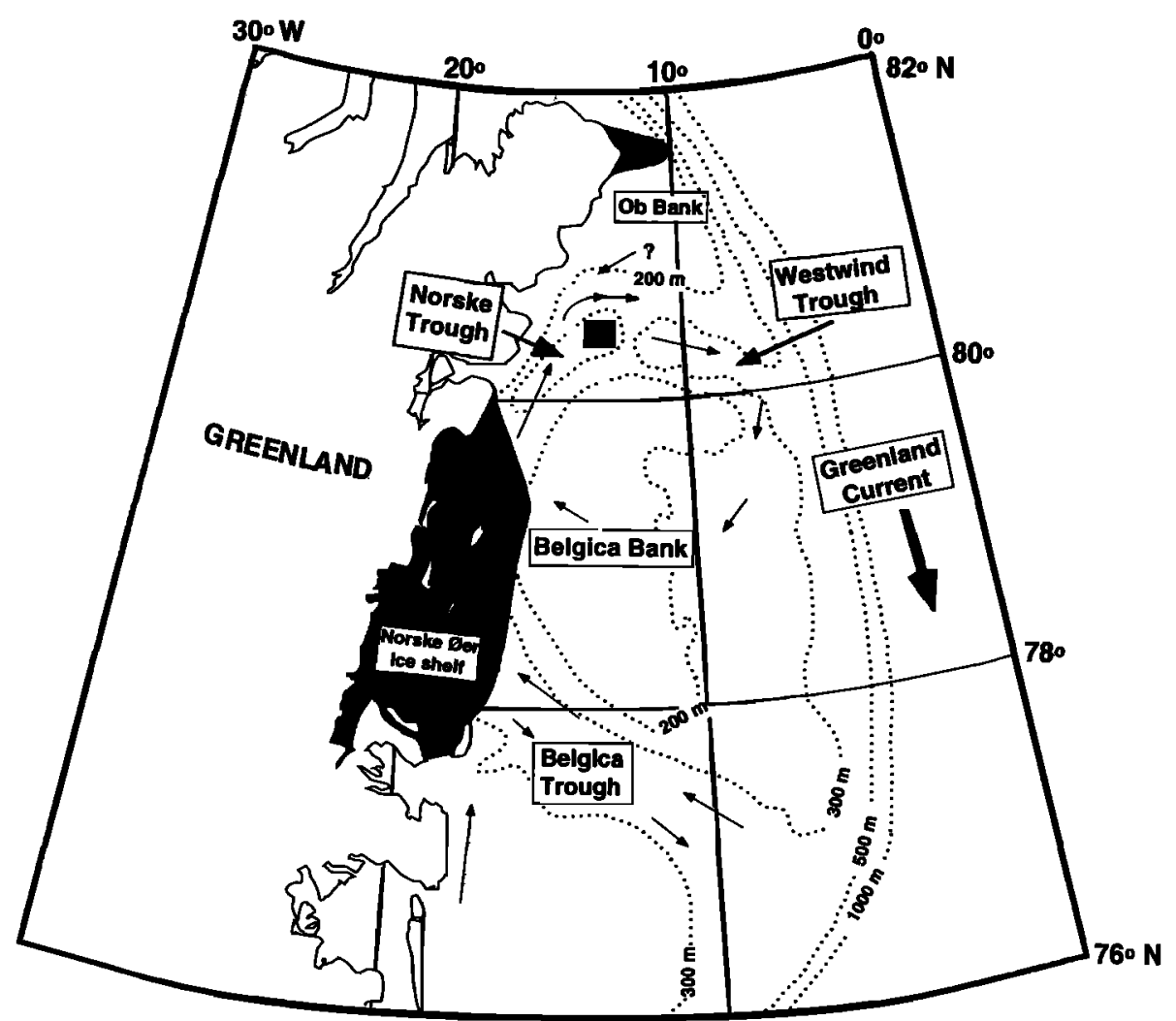

Figure 1. Location of the study area on the northeast Greenland shelf. Dotted lines are depth contours, the large arrow indicates the direction of the Greenland Current along the shelf edge, small arrows indicate the general circulation on the shelf [Budéus and Schneider, 1995; Johnson and Niebauer, 1995], and square indicates location of time series station. Shading designates ice shelves.

containers filled with water collected from the depth of the chlorophyll maximum. All experimental containers were held in the dark at in situ temperatures $\left(-1.5^{\circ}\right.$ to $\left.-1.0^{\circ} \mathrm{C}\right)$ for the duration of the experiment. The methods for measuring egestion, respiration, and excretion rates are described by Daly [1995, 1997]. Briefly, for carbon and nitrogen egestion rates, 2 to 4 Calanus or Metridia were placed in 70 - or $90-\mathrm{mL}$ glass jars containing water from the chlorophyll maximum. Rates measured in these jars were similar to those for copepods held in 2-L jars. The jars also held an inner plastic cylinder with a $500-\mu \mathrm{m}$ mesh bottom to prevent the reingestion of fecal material. After 3 to 5 hours, pellets were siphoned onto combusted $\mathrm{GF} / \mathrm{F}$ filters, rinsed briefly with distilled water, excess water was removed by hand pump, and the filters were frozen. Blanks were determined by using two filters (layered) for one of the replicates in each experiment. Copepods also were rinsed, blotted dry, and frozen. In the laboratory, pellets and copepods were dried at $60^{\circ} \mathrm{C}$, the copepods weighed, and then both were analyzed for particulate carbon and nitrogen on the $\mathrm{CHN}$ analyzer. For carbon dioxide and oxygen respiration and ammonium and phosphate excretion rates, 13 to $18 C$. hyperboreus females were held in three to five 1-L bottles containing filtered $(0.7 \mu \mathrm{m})$ seawater with zero headspace for about 24 hours along with two control bottles. Rate measurements were determined from subsamples siphoned from the same experimental bottles using the methods described above for water column inventories. Copepods were frozen and then were dried at $60^{\circ} \mathrm{C}$, weighed, and measured for particulate carbon and nitrogen content in the shore-based laboratory.

Community respiration and excretion rates in Table 4 are the summation of daily release by life history stages of Calanus hyperboreus, C. glacialis, C. finmarchicus, Metridia longa, and Pseudocalanus minutus collected within known depth intervals by MOCNESS nets. Methods for zooplankton collection are described by Ashjian et al. [1995] and 1993 abundance data are from $\mathrm{S}$. Smith et al. (unpublished data, 1995). Rates for female C. hyperboreus were measured, but for other stages and species, $\mathrm{CO}_{2}$ production was estimated from oxygen consumption rates or respiration as a percent daily loss of body carbon using weight-specific rates for females, dry weights of life history stages (CI - CV, females), and abundance of each stage of copepod within depth intervals. Rates for copepodite stages $\mathrm{CI}-\mathrm{CV}$ were assumed to be proportional to dry body weight [Ikeda, 1985]. Rates of $\mathrm{CO}_{2}$ production and ammonium excretion for $C$. glacialis are from Bämstedt and Tande [1985] and Tande [1988], respectively; those for C. finmarchicus are from Ikeda and Skjoldal [1989] and Mayzaud [1976], respectively; those for Metridia are from Haq [1967] and Bämstedt et al. [1985], respectively; and Pseudocalanus values are from Bedo et al. [1990]. Dry weight and body carbon data are from Conover and Huntley [1991], Corkett and McLaren [1978], Daly [1997], Eilertson et al. [1989], Poulet [1978], and Smith [1988]. 
Table 1. Molar Concentrations, Rates, and Ratios of Carbon and Nitrogen Associated With Dissolved and Particulate Pools in the Euphotic Zone of Coastal Greenland

\begin{tabular}{|c|c|c|c|c|}
\hline $\begin{array}{c}\text { Euphotic Zone Pools } \\
\text { and Rates }\end{array}$ & $\begin{array}{l}\text { Number } \\
\text { of } \\
\text { Samples }\end{array}$ & Median & Range & $\mathrm{C}: \mathrm{N}^{*}$ \\
\hline & \multicolumn{4}{|c|}{ Dissolved Pool } \\
\hline $\begin{array}{l}\mathrm{DIC} \\
\mathrm{NO}_{3} \\
\mathrm{NH}_{4}\end{array}$ & $\begin{array}{l}373 \\
456 \\
456\end{array}$ & $\begin{array}{l}2073 \\
1.40 \\
0.00\end{array}$ & $\begin{array}{l}1385-2158 \\
0.00-13.7 \\
0.00-0.88\end{array}$ & \\
\hline $\begin{array}{l}\text { DIC:NO } \\
\text { DOC } \\
\text { DON } \\
\text { DOC:DON }\end{array}$ & $\begin{array}{r}17 \\
182 \\
182 \\
182\end{array}$ & $\begin{array}{l}105 \\
5.82\end{array}$ & $\begin{array}{c}9-414 \\
0.97-9.77\end{array}$ & $19.3(18.3-19.6)$ \\
\hline DOC:DON & \multicolumn{4}{|c|}{ Particulate Pool } \\
\hline \multicolumn{5}{|l|}{ Microplankton } \\
\hline $\begin{array}{l}\text { POC } \\
\text { PON } \\
\text { POC:PON } \\
\text { C uptake } \\
\mathrm{NO}_{3} \text { uptake } \\
\mathrm{NH}_{4} \text { uptake } \\
\mathrm{C} \text { : total } \mathrm{N}\end{array}$ & $\begin{array}{l}299 \\
299 \\
299 \\
290 \\
292 \\
292 \\
287\end{array}$ & $\begin{array}{l}10.9 \\
1.30 \\
\\
66.8 \\
1.94 \\
1.35\end{array}$ & $\begin{array}{l}0.20-51.7 \\
0.10-11.9 \\
0.20-699 \\
0.00-108 \\
0.00-23.9\end{array}$ & $8.90(8.50-9.30)$ \\
\hline \multicolumn{5}{|l|}{ Copepods } \\
\hline $\begin{array}{l}\text { Body C } \\
\text { Body N }\end{array}$ & $\begin{array}{l}84 \\
84\end{array}$ & $\begin{array}{l}70.5 \\
7.40\end{array}$ & $\begin{array}{l}17.5-321.9 \\
1.90-28.5\end{array}$ & \\
\hline Body C:N & 84 & & & $9.60(8.90-10.4)$ \\
\hline $\mathrm{CO}_{2}$ respiration & 10 & 61.5 & $32.1-86.3$ & \\
\hline $\mathrm{NH}_{4}$ excretion & 13 & 7.12 & $2.68-14.3$ & \\
\hline $\mathrm{CO}_{2}: \mathrm{NH}_{4}$ & 5 & & & $8.8(4.60-16.4)$ \\
\hline C egestion & 24 & 263.4 & $32.3-653.4$ & \\
\hline $\mathrm{N}$ egestion & 24 & 6.60 & $1.30-93.6$ & \\
\hline$C: N$ egestion & 24 & & & $33.2(22.8-48.0)$ \\
\hline
\end{tabular}

For comparison, the Redfield [Redfield et al., 1963] C:N ratio is 6.6 and the Takahashi [Takahashi et al., 1985] ratio is 7.6. Dissolved inorganic carbon (DIC), nitrate $\left(\mathrm{NO}_{3}\right)$, ammonium $\left(\mathrm{NH}_{4}\right)$, dissolved organic carbon (DOC) and nitrogen (DON), particulate organic carbon (POC) and nitrogen (PON) are in $\mu$ moles $\mathrm{L}^{-1}$; carbon and nitrogen $\left(\mathrm{NO}_{3}+\mathrm{NH}_{4}\right)$ uptake by phytoplankton is in $\mathrm{nmol} \mathrm{L} \mathrm{L}^{-1}$ $\mathrm{h}^{-1}$. Copepods were female Calanus hyperboreus; body carbon (C) and nitrogen $(\mathrm{N})$ are in $\mu \mathrm{mol}$, carbon dioxide respiration $\left(\mathrm{CO}_{2}\right)$, ammonium excretion, and carbon and nitrogen egestion are in $\mathrm{nmol}$ ind ${ }^{-1} \mathrm{~h}^{-1}$. The euphotic zone was $<70 \mathrm{~m}$.

* C:N ratios are geometric mean ratios with $95 \%$ confidence intervals in parentheses, except the consumption ratio (DIC: $\mathrm{NO}_{3}$ ) was estimated by the geometric mean regression $(95 \% \mathrm{CI})$ of salinitynormalized anomalies integrated $0-70 \mathrm{~m}$.

\subsection{Data Analyses}

The effect of biological processes on total dissolved inorganic carbon was calculated following the methods described by Yager et al. [1995], which corrected for physical-chemical processes including dilution from sea ice melt and river input, calcium carbonate precipitation or dissolution, and atmospheric gas exchange due to warming or diffusion. The biological removal of DIC by animals with $\mathrm{CaCO}_{3}$ shells appeared to be minimal since the regression of alkalinity on salinity did not suggest any evidence of nonconservative behavior with respect to calcium carbonate. Wind speed was low during the study $\left(0-4 \mathrm{~m} \mathrm{~s}^{-1}\right)$, and thus estimation of diffusive gas exchange from the atmosphere was negligible [D. Wallace, unpublished data, 1997].

In previous studies, $C: N$ stoichiometry usually has been determined by the model I regression, the mean of ratios of paired data (i.e., $\bar{X}$ of $\mathrm{C}: \mathrm{Ns}$ ), or as the ratio of the means of paired data [i.e., $(\bar{X}$ of $\mathrm{C}) /(\bar{X}$ of $\mathrm{N})$, with no variance]. These approaches are inappropriate for two reasons: (1) there is random and/or measurement error in $x$ and $y$, and (2) these data often are not normally distributed [Ricker, 1973; McArdle, 1988]. Here we use either the geometric mean (GM) model II regression, the median, or the geometric mean ratio as a measure of central tendency (see Table 1), the latter being a better measure for ratio or rate data with a skewed or lognormal distribution [Zar, 1984]. The arithmetic mean overestimates the central trend for positively skewed lognormal frequency distributions (long right-hand tail), such as is common for biological data in marine systems, whereas both the geometric mean and the median are less sensitive to anomalies due to sample size and therefore are a more consistent or conservative measure of a variable to compare across different 

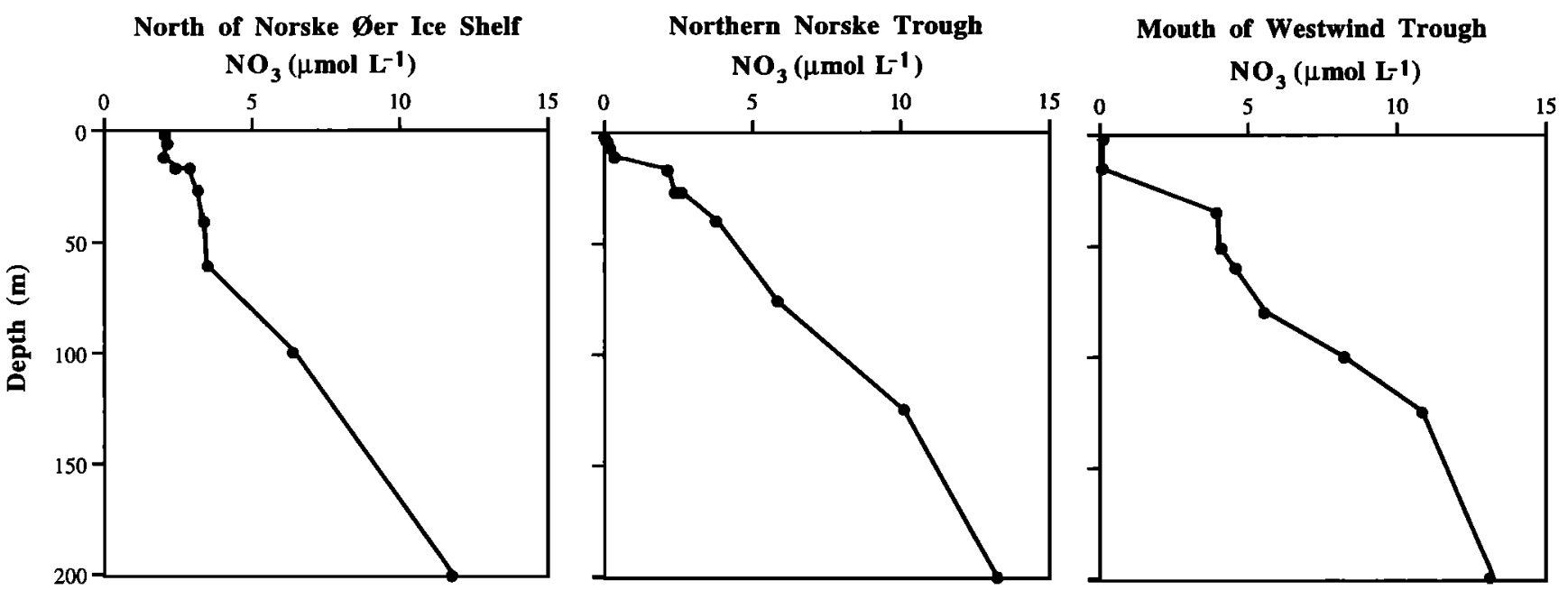

Figure 2. Along-trough vertical profiles of nitrate concentration at three stations in midchannel chosen to represent the downstream depletion of nutrients during August. Relatively high nitrate concentrations were observed in water emerging from under the Norske Der ice shelf, but nitrate was depleted in surface water by the time series station and was generally low farther downstream in the Westwind Trough.

systems. Statistical tests were made at a $5 \%$ significance level. Predictive regressions for $Y$ on $X$ were estimated by the ordinary least squares (LSR) method [Zar, 1984].

\section{Results}

During our study, only the molar C:N ratios for dissolved inorganic carbon to nitrate consumption and for copepod respiration to excretion were not significantly different $(\alpha=0.05)$ from Redfield-Takahashi stoichiometry; all other C:N ratios exceeded $(p<0.001)$ Redfield-Takahashi proportions (Table 1).

\subsection{Dissolved Pool}

Important features of our study area include the following. (1) An advective supply of water containing approximately 4 $\mu M$ of nitrate supported production throughout summer [Wallace et al., 1995; Kattner and Budéus, 1997]. In the upper $5 \mathrm{~m}$ of the water column, nitrate often was near or below the limit of detection (approximately $0.05 \mu M$ ), increasing to 3 - $5 \mu \mathrm{M}$ at the base of the euphotic zone (Figure 2). (2) Ammonium concentrations were near or below detection (approximately $0.05 \mu M$ ). (3) Silicate concentrations decreased (from approximately 14 to $<2 \mu M$ ) within the study area, reflective of diatom growth. The median concentrations of DIC, nitrate, and ammonium in the euphotic zone were 2073, 1.40, and $0.00 \mu M$, respectively (Table 1 ). Phosphate concentrations (range, 0.07 to $1.06 \mu M$ ) were never below detection limits in surface waters. Nitrate increased from approximately. 5 to $7 \mu M$ between 50 and $100 \mathrm{~m}$ to approximately 13 $\mu M$ below 150 to $200 \mathrm{~m}$ in depth, whereas phosphate showed little variation in deeper water (about $1.0 \mu M$ ).

Seasonal anomalies of DIC, nitrate, dissolved organic carbon (DOC), and dissolved organic nitrogen (DON) driven by net biological processes are estimated by comparing salinitynormalized concentrations integrated over the euphotic zone $(<70 \mathrm{~m})$ with "baseline" values measured below the euphotic zone, but in the same water mass $(70-100 \mathrm{~m})$ [Wallace et al.,
1995], since temperature and salinity data for the study region indicated that the upper $100 \mathrm{~m}$ of the water column were well mixed by convection during winter. Regressions of nutrient inventories from the subeuphotic zone $(70-100 \mathrm{~m})$ showed little change over time (slope $=0 ; p=0.05$ ), suggesting that nutrient regeneration was not occurring at these depths during the study

The slope (9.8) of the model II regression of DIC anomalies on nitrate anomalies (Table 1) for stations along a downstream transect in the polynya was not significantly different from either the Redfield molar C:N ratio (6.6) or the ratio (7.6) proposed by Takahashi et al. [1985]. Thus the null hypothesis that seasonal net biological processes approximated Redfield stoichiometry could not be rejected based on DIC:nitrate consumption or surface loss relative to deep water (winter) concentrations. The DIC consumption relative to particulate organic carbon (POC) accumulation (DIC:POC = 1.6) was nearly in balance given loss terms, such as grazing and phytoplankton release of $\mathrm{DOC}$.

In contrast, the dissolved organic pool greatly exceeded the Redfield-Takahashi ratios. DOC appeared to be uncoupled from DON (linear regression coefficient, $b=0, p=0.301$ ). DOC concentrations were much higher in the surface layer compared to deep water, whereas there was little vertical gradient for DON. Because the DOC and DON concentrations for our study were measured during the beginning of the bloom in late May and June, it is not known whether concentrations increased by August. Using median concentrations from 70 to $100 \mathrm{~m}(100 \mu M$ DOC, $5.32 \mu M$ DON) as a baseline for winter surface concentrations, the median dissolved organic matter anomalies for the upper $70 \mathrm{~m}$ reached by early July were $23 \mu M$ DOC (range, 5 to $68 \mu M$ ) and $<1 \mu M$ DON (range, -1.47 to $0.39 \mu M$ ).

\subsection{Particulate Pool: Phytoplankton}

The distribution pattern of particulate organic carbon and nitrogen was variable over the study area, with median concentrations in the euphotic zone of 10.9 and $1.30 \mu M$, respec- 


\section{C:N}

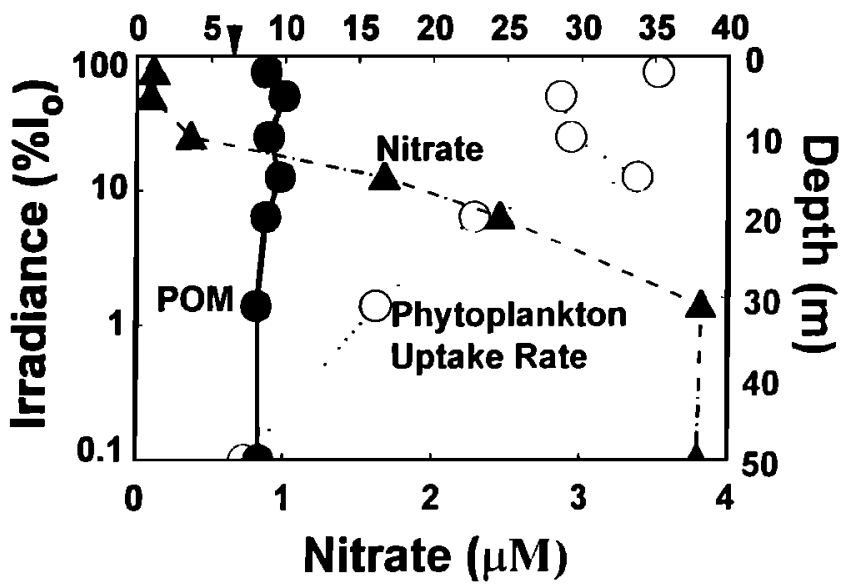

Figure 3. Vertical distribution of molar $\mathrm{C}: \mathrm{N}$ ratios of particulate organic matter (POM) (number of samples, $n=79$ ) and phytoplankton uptake rates $(n=42)$ versus irradiance levels and nitrate concentration $(n=53)$ versus depth in the euphotic zone. Nitrogen $(\mathrm{N})$ uptake rates are nitrate plus ammonium assimilation. Owing to averaging affects, irradiance levels do not necessarily correspond to depths for nitrate. Ratio data are geometric means, and nitrate data are medians; arrow designates the Redfield $\mathrm{C}: \mathrm{N}$ value for reference. The $95 \%$ confidence intervals for POM, phytoplankton uptake rates, and nitrate at the surface are 8.06 to $9.35 \mu M, 21.9$ to $55.9 \mu M$, and 0.04 to $0.11 \mu M$, respectively.

tively (Table 1). Elevated primary production and accumulation of particulate organic matter (POM) covaried, with maximum rates and concentrations observed at the northern end of the polynya in the vicinity of the time series station. The average depth of primary productivity and POM maxima was about $5 \mathrm{~m}$, while the depth of the chlorophyll $a$ maximum was deeper (approximately $10 \mathrm{~m}$ ).

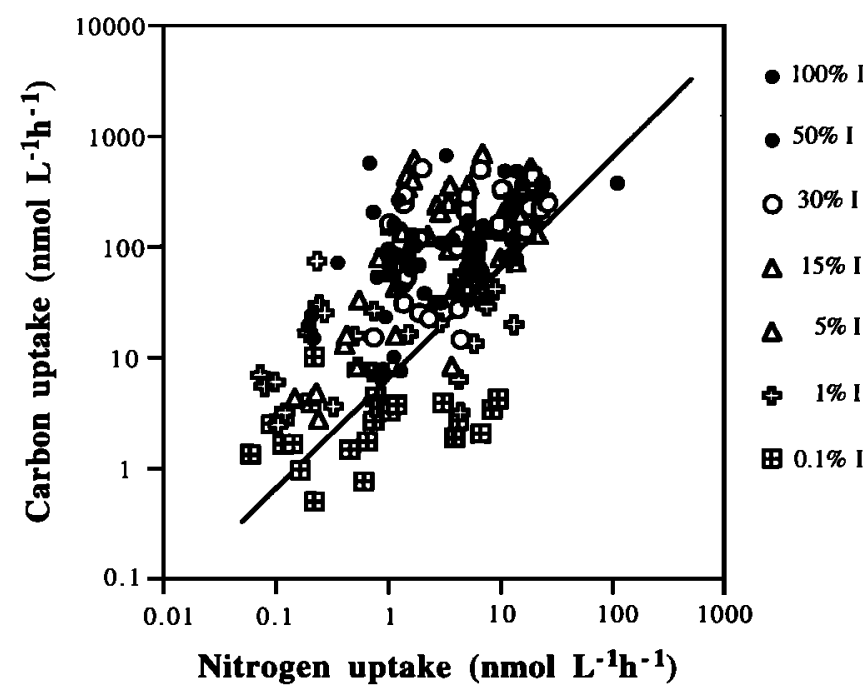

Figure 4. Log plot of carbon and nitrogen uptake rates by phytoplankton as a function of irradiance. Irradiance (I) fields are a percentage of the surface level; total nitrogen uptake is nitrate plus ammonium assimilation. Line shows Redfield ratio for comparison $(C: N=6.6)$.
The C:N ratios for POM were moderately elevated through the euphotic zone relative to Redfield-Takahashi stoichiometry, whereas the $\mathrm{C}: \mathrm{N}$ ratios of phytoplankton uptake rates $(\mathrm{N}=$ nitrate plus ammonium assimilation) were significantly higher, particularly near the surface (Figure 3). The influence of detritus on the particulate $\mathrm{C}: \mathrm{N}$ ratio could not be examined using the conventional LSR regression approach [e.g., Banse, 1974, 1977], because POC, PON, and chlorophyll had lognormal distributions and thus did not meet the assumptions of parametric regression [Zar, 1984].

Although the detrital contribution to particulate matter could not be directly assessed, nutrient limitation and the species composition of phytoplankton appear to have influenced the elevated ratios for POM and phytoplankton uptake rates throughout the productive season based on the following observations: (1) the highest $C: N$ ratios of uptake rates by phytoplankton occurred at higher irradiance and relatively low nitrate concentrations and only approached Redfield near the bottom of the euphotic zone at low irradiance and relatively high nutrient levels (Figures 3 and 4); (2) the numerical and biomass dominant phytoplankton species in productive areas was the colonial Chaetoceros socialis, a diatom that has small cells (about $10 \mu \mathrm{m}$ ) embedded in a mucilaginous sheath [Drebes, 1974; Hasle and Fryxell, 1995; Booth and Smith, 19971, which would have contributed to a higher carbon content relative to nitrogen (other dominant species included the chain-forming diatoms, Fragilariopsis oceanica and Thalasstosira hyalina, $20-100 \mu \mathrm{m}$ in size); (3) size-fractionated
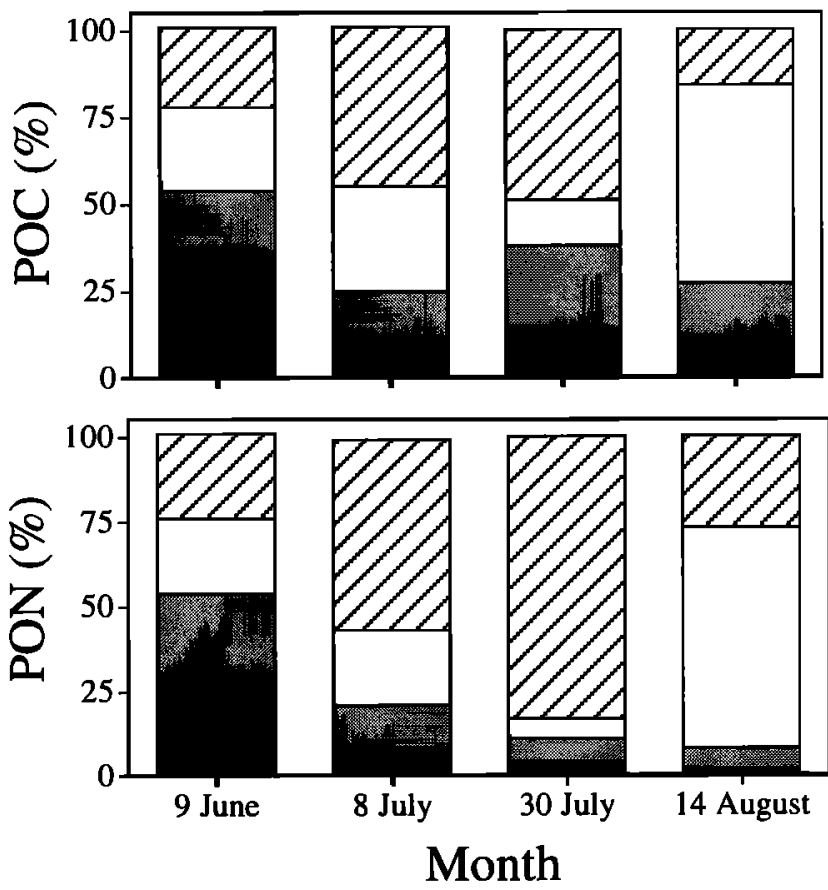

Figure 5. Percentage of carbon (POC) and nitrogen (PON) in size fractions of particulate organic matter. Samples are from depth of the chlorophyll maximum ( 5 to $27 \mathrm{~m}$ ); nitrate concentrations are $3.76,2.63,0.83$, and $2.14 \mu M$, respectively, for June 9 to August 14. June 9 station, $9 / 10$ ice cover; other stations, 0 to $1 / 10$ ice cover. Key for size fractions is as follows: hatching, < $20 \mu \mathrm{m}$; white, $20-100 \mu \mathrm{m}$; gray, $100-200 \mu \mathrm{m}$; and black $>200 \mu \mathrm{m}$. 


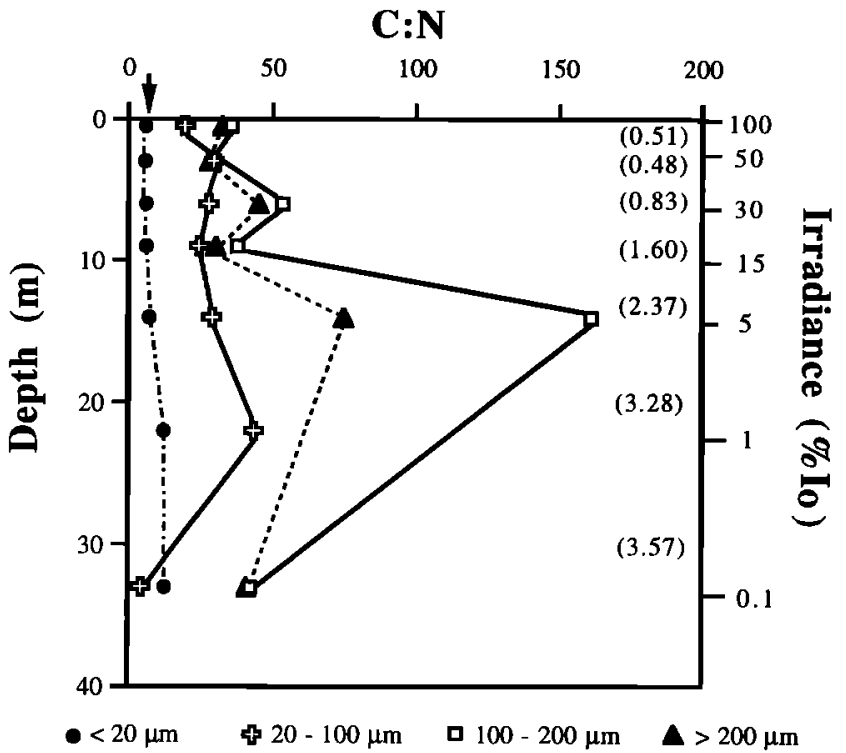

Figure 6. Vertical distribution of molar $\mathrm{C}: \mathrm{N}$ ratios for different size fractions of particulate organic matter in the euphotic zone. Samples are from the time series station, July 30, 1993. Sea ice cover is $0 \%$, nitrate concentrations $(\mu \mathrm{mol} \mathrm{kg})^{-1}$ ) are in parentheses; particulate matter maximum (POC, $20.8 \mu M$; PON, $2.47 \mu M$ ) is at $3 \mathrm{~m}$, chlorophyll maximum $\left(2.7 \mu \mathrm{g} \mathrm{L}^{-1}\right)$ is at $9 \mathrm{~m}$. Arrow designates the location of the Redfield C:N for reference

particulate matter at the time series station during June, July, and August suggested that the percentage of nitrogen was lower than carbon in the larger size fractions (Figure 5); (4) vertical profiles of size fractions indicate that only the $<20$ $\mu \mathrm{m}$ fraction approached Redfield proportions throughout the euphotic zone, while all other fractions exceeded Redfield, especially at shallow and intermediate depths (Figure 6); and (5) the average $\mathrm{C}: \mathrm{N}$ ratio of POM [geometric mean $(95 \% \mathrm{CI}): 8.9$ $(8.4$ - 9.6)] from May to July was not significantly different $(p$ $=0.55$ ) from that in August (8.9); thus elevated C:N ratios of particulate matter appear to be typical for most of the productive season.

The actual $\mathrm{C}: \mathrm{N}$ ratio of phytoplankton uptake rates was probably similar to the C:N ratio of POM, because urea was likely an important source of nitrogen in addition to nitrate and ammonium for phytoplankton growth. Urea uptake was not measured during August, but it was measured from May to early July. The mean uptake rate $(\bar{X} \pm 1$ standard deviation; $004 \pm 0.06 \mathrm{mmol}$ urea $\left.\mathrm{m}^{-2} \mathrm{~h}^{-1}\right)$ was similar to the mean ammonium uptake $\left(0.04 \pm 0.09 \mathrm{mmol} \mathrm{m}^{-2} \mathrm{~h}^{-1}\right)$, and the uptake ratios for May to July ( $\mathrm{C}: \mathrm{N}=8.7$ ) were similar to the ratio for particulate matter $(\mathrm{C}: \mathrm{N}=8.9$ ). If urea uptake is excluded from those total nitrogen calculations, then the uptake ratio (11.9) in early summer was not significantly different $(p=$ 0.42) from the uptake ratio in August. Hence total nitrogen assimilation was likely underestimated in August, resulting in an overestimation of the uptake ratio.

Estimates of new production were calculated using different conversion factors prevalent in the literature, including Redfield and Takahashi $\mathrm{C}: \mathrm{N}$ ratios and the ratios from the $\mathrm{CO}_{2}: \mathrm{NO}_{3}$ reduction, POM, and phytoplankton uptake rates measured during this study, to examine the variation between conversion factors (Table 2). The Redfield ratio yielded the lowest estimate of carbon export to deep water, whereas the C:nitrate uptake rates gave the highest. During August median-integrated primary production was $68.4 \mathrm{mmol} \mathrm{C} \mathrm{m} \mathrm{m}^{-2} \mathrm{~d}^{-1}$ (range, 11.3 to $225.3 ; n=44$ ), and the median integrated rate of nitrate assimilation was $3.98 \mathrm{mmol} \mathrm{N} \mathrm{m} \mathrm{d}^{-1}$ (range, 0.39 to $10.75, n=37$ ). The mean $f$ ratio (nitrate uptake/(nitrate + ammonium uptake) [Eppley and Peterson, 1979]) for the euphotic zone was $0.59 \pm 0.26$ (median 0.60 ), suggesting that more than half of the primary production was supported by nitrate and therefore was "new production." However, if urea uptake was similar to ammonium uptake during August, then the $f$ ratio would be lower $(0.42)$ and production would have been more dependent on regenerative processes.

\subsection{Particulate Pool: Zooplankton}

The dominant Arctic zooplankton species collected in the surface layer during this study included the herbivorous copepods Calanus hyperboreus and C. glacials; the omnivorous Metridia longa occurred deeper in the water column. In Table 1 the carbon and nitrogen content and rates measured for $C$. hyperboreus copepodite stage $\mathrm{V}$ and females were used as a proxy for near-surface copepods. On average, $54.9 \%$ of the dry weight of individuals was carbon and $7.3 \%$ was nitrogen. The molar C: $\mathrm{N}$ ratio of copepod body carbon to nitrogen (9.6, Table 1) was significantly higher $(p<0001)$ than RedfieldTakahashi ratios, but not significantly different $(p=0.136)$ than the ratio for particulate matter.

The turnover of carbon and nitrogen in females (percent daily loss of body carbon and nitrogen) as a result of metabolic processes was calculated as the ratio of $\mathrm{CO}_{2}$ released to ammonium excreted per individual. This metabolic ratio $\left(\mathrm{CO}_{2}: \mathrm{NH}_{4}=8.8\right)$ was not significantly different from Redfield $(p=0.278)$ or Takahashi $(p=0.550)$ values and not significantly different $(p=0.617)$ from the body $\mathrm{C}: \mathrm{N}$ ratio. Only ammonium-N excretion, however, was measured during this study. If female copepods excreted substantial amounts of

Table 2. Range of Estimated Carbon-Equivalent New Production

\begin{tabular}{lc}
\hline \multicolumn{1}{c}{ Conversion Factor } & $\begin{array}{c}\text { New Production, } \\
\mathrm{mmol} \mathrm{C} \mathrm{m}^{-2} \mathrm{~d}^{-1}\end{array}$ \\
\hline Redfield $\mathrm{C}: \mathrm{N}=6.6$ & 26.3 \\
Takahashi C:N $=7.6$ & 30.2 \\
POC:PON $=8.9$ & 35.4 \\
C:N* uptake $=8.9$ & 35.4 \\
DIC:NO & drawdown $=9.8$ \\
\hline
\end{tabular}

Sources include Redfield et al. [1963] and Takahashi et al. [1985]. New production was estimated from median-integrated rate of nitrate uptake by phytoplankton $\left(398 \mathrm{mmol} \mathrm{NO}_{3}\right.$ uptake $\left.\mathrm{m}^{-2} \mathrm{~d}^{-1}\right)$ and different conversion factors converting nitrogen $(\mathrm{N})$ to carbon (C)

*Geometric mean of uptake rates was measured at $30-100 \%$ of surface irradiance; $\mathrm{N}$ is sum of nitrate, ammonium, and urea assimilation rates. 
Table 3. Mass Balance Estimate of Potential Dissolved Organic Carbon and Nitrogen Excretion by Female Calanus hyperboreus

\begin{tabular}{l|cccc|ccc|c}
\hline \multicolumn{1}{c|}{ Budget } & $I$ & $R$ & $E$ & $G+U$ & $A I$ & $K_{2}$ & $G$ & $(G+U)-G=U$ \\
\hline Carbon & 16.3 & 1.35 & 5.39 & 9.56 & 10.9 & $40 \%$ & 4.36 & 5.20 \\
Nitrogen & 1.81 & 0.152 & 0.163 & 1.49 & 1.64 & $0 \%$ & 0.00 & 1.49 \\
\hline
\end{tabular}

Variables are $I$, ingestion; $R$, respiration; $E$, egestion; $G$, growth (i.e., lipid storage); $U$, organic excretion (formula used is $l-(R+E)=G+U) ; A l$, assimilated food; $K_{2}$, ratio of growth to assimilated food $\left[A I\left(K_{2}\right)=G\right]$; units are $\mu \mathrm{mol}$ ind $^{-1} \mathrm{~d}^{-1}$. Numbers for carbon and nitrogen budgets from Table 1 were converted to daily rates. Net growth efficiency was measured for $C$. hyperboreus $\mathrm{CV}$ at $2^{\circ}$ to $5^{\circ} \mathrm{C}$ [Conover, 1964].

urea or amino acids, then nitrogen excretion would be underestimated. In contrast, the ratio of carbon to nitrogen egestion per individual was significantly higher $(p \leq 0.001)$ than Redfield or Takahashi ratios. During our study, copepods assimilated nitrogen more efficiently than carbon [Daly, 1997] and egested a higher proportion of carbon than nitrogen in fecal pellets, suggesting that this component of sinking material was carbon rich.

Dissolved organic carbon and nitrogen excretion by $C$. $h y$ perboreus females was estimated using a mass balance approach (Table 3 ). The carbon and nitrogen budget for a copepod may be described as

$$
I=G+R+E
$$

where $I$ is the dally amount of carbon or nitrogen ingested, $G$ is the amount allocated to growth, $R$ is the amount of carbon dioxide released or nitrogen excreted in catabolism, and $E$ is the amount egested in fecal pellets. This budget assumes that "growth" in female $C$. hyperboreus is primarily due to lipid storage because these females do not molt or reproduce during summer. Because lipids contain little nitrogen, the nitrogen requirement for $G$ was assumed to be negligible. $R$ and $E$ were experimentally determined $\left(1.35 \mu \mathrm{mol} C\right.$ respired ind ${ }^{-1}$ $\mathrm{d}^{-1}, 0.152 \mu \mathrm{mol} \mathrm{N}$ excreted $1 \mathrm{nd}^{-1} \mathrm{~d}^{-1}$, respectively). I was estimated from $E$ and an average assimilation efficiency per individual $(67 \%$ for carbon [Conover, 1966a] and 91\% for nitrogen [Daly, 1997]) to be $16.3 \mu \mathrm{mol} \mathrm{C}$ and $1.81 \mu \mathrm{mol} \mathrm{N}$ ingested ind ${ }^{-1} \mathrm{~d}^{-1}$. Thus the fraction of ingested food $\left(0.67 I_{c}\right.$ and $0.91 I_{n}$ ) that was assimilated through the gut wall and available for metabolic degradation or growth was equivalent to $10.9 \mu \mathrm{mol} \mathrm{C}$ and $1.64 \mu \mathrm{mol} \mathrm{N}$. From (1) the unused carbon and nitrogen remaining after metabolic and egestion losses is calculated to be $9.56 \mu \mathrm{mol} \mathrm{C}$ and $1.49 \mu \mathrm{mol} \mathrm{N}$. Assuming a net growth efficiency $K_{2}$ of $40 \%$ [Conover, 1964], growth was estimated to be $436 \mu \mathrm{mol} \mathrm{C}$ ind $^{-1} \mathrm{~d}^{-1}$, leaving $5.20 \mu \mathrm{mol} \mathrm{C}$ remaining for DOC excretion. Similarly, if nitrogen-based growth was negligible, then $1.49 \mu \mathrm{mol} \mathrm{N}$ ind $\mathrm{d}^{-1} \mathrm{~d}^{-1}$ may have been excreted as DON or other dissolved inorganic nitrogen products, such as urea. On the bases of these calculations, of the carbon ingested, $8 \%$ was respired, $33 \%$ was egested, and $27 \%$ may have been used in lipid storage (i.e., growth), and $32 \%$ was excreted as DOC (or diffused from fecal pellets). Similarly, of the nitrogen ingested, $8 \%$ was excreted as ammonium, $9 \%$ was egested, and the remaining proportion of assimilated nitrogen ( $83 \%$ ) may have been excreted as DON.

\subsection{Trophic Interactions}

We also examined trophic interactions that could influence carbon and nitrogen cycling using data from the time series station located in a productive region of the polynya. Within the upper $20 \mathrm{~m}$ of the water column (where zooplankton and phytoplankton were most abundant), the copepod community, on average, excreted $38.6 \pm 21.7 \mu \mathrm{mol} \mathrm{CO} \mathrm{CO}^{-3} \mathrm{~d}^{-1}$ and $2.5 \pm$ $1.7 \mu \mathrm{mol} \mathrm{NH} \mathrm{Nm}_{4}^{-3} \mathrm{~d}^{-1}$ to the dissolved pool and contributed $367 \pm 250 \mu \mathrm{mol} \mathrm{C} \mathrm{m} \mathrm{d}^{-1}$ and $11.5 \pm 7.8 \mu \mathrm{mol} \mathrm{N} \mathrm{m} \mathrm{d}^{-3}$ to the particulate pool as fecal pellets. Over the euphotic zone the integrated primary production and ammonium uptake by phytoplankton and the potential daily rate of $\mathrm{CO}_{2}$ release, ammonium excretion, and carbon and nitrogen particulate egestion by life history stages of all species of copepods are shown in Table 4. Copepod respiration accounted for approximately $1 \%$ of phytoplankton $\mathrm{CO}_{2}$ demand and ammonium excretion provided approximately $8 \%$ of the daily ammonium taken up by phytoplankton. The integrated rate of community ingestion, estimated from the carbon egestion rate and a conservative carbon assimilation efficiency per individual of $67 \%$ [Conover, 1966a], indicated that copepods consumed, on average, $41 \%$ (range, $8-65 \%$ ) of the primary production at this location. The integrated rate of copepod carbon egestion was 1 to 2 orders of magnitude higher than nitrogen egestion. Thus copepods, via grazing and egestion, could significantly influence the composition and elemental content of the particulate matter and the particulate flux in this region.

\section{Discussion}

In the Arctic Ocean and its marginal seas, phytoplankton growth is strongly controlled by environmental factors, such as low seawater temperature, nutrient concentrations, and irradiance [Smith and Harrison, 1991]. Prior to the summer bloom, hydrographic conditions of surface water were dominated by cold, low-salinity Polar Water $\left(<0^{\circ} \mathrm{C},<33.0 \mathrm{psu}\right.$ [Budéus and Schneider, 1995]) and low nutrient inventories (nitrate, silicate, and phosphate concentrations of approximately 4, 10 and $1 \mu M$, respectively [Wallace et al., 1995]). During June and July, nitrate and silicate levels decreased, whereas phosphate remained at low levels. By August, temperatures in the upper 2 to $5 \mathrm{~m}$ of the water column in open water were $>0^{\circ} \mathrm{C}$ (maximum $4.6^{\circ} \mathrm{C}$ ) and nitrate concentrations were depleted in near-surface waters where phytoplankton uptake rates were highest. Owing to ice melt and thermal 
Table 4. Integrated Rates for Phytoplankton and Zooplankton in the Euphotic Zone at the Time Series Station

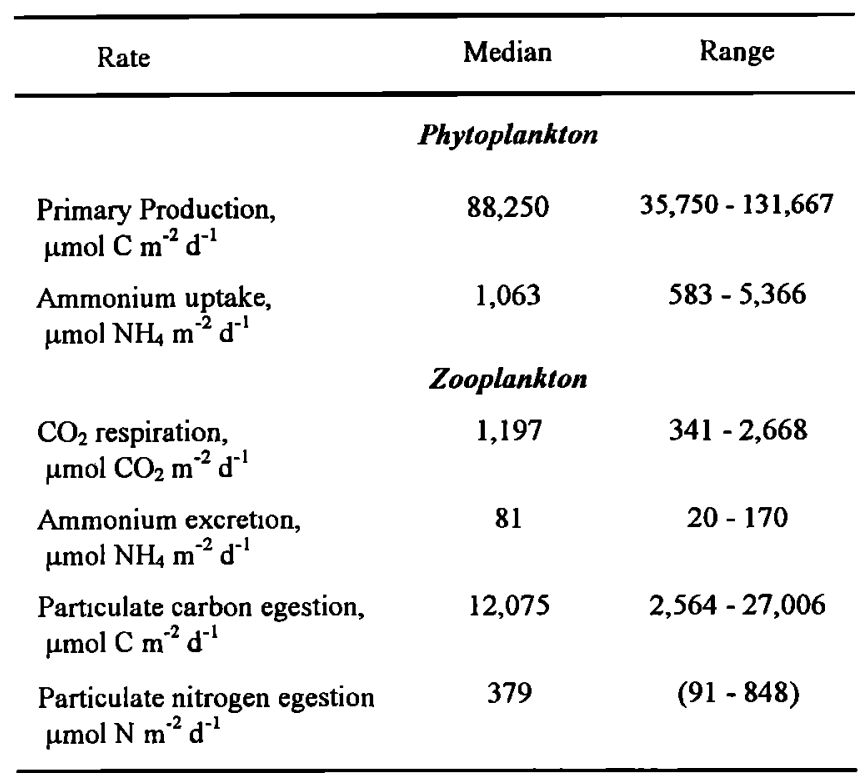

Zooplankton rates were estimated from abundances of life history stages of all species of copepods and weight-specific rate measure-ments. Phytoplankton, $n=$ seven bottle casts; zooplankton, $n=$ four discrete-depth MOCNESS net series. Copepod abundance data are from S. Smith et al. (unpublished data, 1995).

heating of the surface layer, the well-developed pycnocline prevented the upward diffusion of nutrients from deep water to the surface layer [Budéus and Schneider, 1995]. Additional nutrients, however, were advected into surface waters of the polynya from under the Norske Øer ice shelf and sporadically across Ob Bank from the East Greenland Current [Kattner and Budeus, 1997], which contributed to the relatively high sustained primary production from June to August at the northern end of the Norske Trough.

\subsection{Factors That Modify $C: N$ Ratios in Surface Waters}

During our study, the consumption of DIC relative to nitrate (molar $\mathrm{C}: \mathrm{N}=9.8$ ) in the euphotic zone during August was not significantly different from Redfield-Takahashi stoichiometry. Although our ratio was within the range reported by Sambrotto et al. [1993] (C:N 8.5 to 14.0), our consumption anomalies, using a model II regression, did not support Sambrotto et al.'s findings of an elevated $\mathrm{C}: \mathrm{N}$ consumption in temperate and high-latitude regions. A recalculation of our data using an LS model I regression for comparison yields a ratio (C:N \pm standard error, $7.9 \pm 1.9, r^{2}=0.65$ ) somewhat lower than Sambrotto et al.'s reported range. Even though our C:N ratio was not significantly different than that of RedfieldTakahashi, the seasonal changes in DIC and nitrate are not necessarily coupled and therefore changes in nitrate concentrations may not accurately reflect community net carbon production [Banse, 1994].

4.1.1. Seasonal DOC accumulation. In contrast to the dissolved inorganic pool, the $\mathrm{C}: \mathrm{N}$ ratio of the seasonal anomalies for the dissolved organic pool greatly exceeded Redfield-Takahashi proportions. Our estimated accumulation of $23 \mu \mathrm{M}$ dissolved organic carbon in the surface layer during the productive season was consistent with that observed in the Norwegian Sea [Borsheim and Myklestad, 1997]. During our study, bacterial abundances $\left(2 \times 10^{5} \mathrm{~mL}^{-1}\right)$ [Yager, 1996] and rates of activity [Ritzau, 1997] were generally low relative to those in temperate waters, suggesting that microbial turnover of DOC was low, which would allow a buildup of C-rich dissolved organic matter (DOM) during summer. Our results support the conclusion of recent studies [Sambrotto et al., 1993; Banse, 1994; Williams, 1995] and comments by Toggweiler [1993] that the dissolved organic pool was important to understanding the uncoupling of organic matter production and nutrient supply in surface waters, as well as carbon export to deep water.

The DOC:DON ratios from our study area are elevated relative to reports from other regions (e.g., C:N $=7-15$ [Williams and Druffel, 1988; Benner et al., 1992; Williams, 1995]), although there are few other studies for comparison. There also is increasing evidence that relatively high DOC concentrations may be characteristic of surface waters in northern high latitudes, compared to those observed at low (e.g., the Sargasso Sea and the central equatorial Pacific, 60 $80 \mu M$ DOC [Carlson et al., 1994; Carlson and Ducklow, 1995]) or southern high latitudes (the Ross Sea, $40-60 \mu M$ DOC [Carlson et al., 1998]). For example, the mean (112 $\mu M$ ) and range of DOC concentrations (Table 1 ) in the surface layer measured in our study are similar to those observed in Bedford Basin, Nova Scotia [Kepkay et al.,1993]; in the Norwegian Sea [Borsheim and Myklestad, 1997]; and in the central Arctic Ocean [Anderson et al., 1994; Wheeler et al., 1996, 1997]. Our median DON concentration also is comparable to that reported for the Greenland Sea in June [Lara et al., 1993] and the Arctic Ocean in August [Wheeler et al., 1997]. A potential source for the high background DOC in Arctic waters is riverine input, but the sources and fate of DOM remain largely unknown.

4.1.2. Phytoplankton nutrient limitation and species composition. Moderately elevated $\mathrm{C}: \mathrm{N}$ ratios of particulate matter occurred for most of the productive season on the Greenland shelf. The average $\mathrm{C}: \mathrm{N}$ assimilation ratio was higher than the ratio for particulate matter; however, this inbalance was resolved when urea uptake rates were included in calculations of the assimilation ratio. Carbon versus nitrogen uptake rates in phytoplankton (Figure 4) and vertical profiles of $\mathrm{C}: \mathrm{N}$ ratios of uptake rates (Figure 3) and size-fractionated particulate matter (Figure 6), suggest that elevated C:N ratios were due to irradiance-nutrient interactions, nutrient limitation, and species composition of larger-sized phytoplankton. The average $\mathrm{C}: \mathrm{N}$ ratio of uptake rates of unfractionated phytoplankton only approached Redfield near the bottom of the euphotic zone (Figure 3). The plot of carbon versus nitrogen uptake rates indicates that low levels of carbon uptake and large variations in nitrogen uptake occurred at depths where light levels were $0.1 \%$ of the surface irradiance (Figure 4 ). Smith and Harrison [1991] noted that carbon and nitrogen uptake rates in polar regions are uncoupled at low irradiance, since carbon uptake saturates at higher irradiance than nitrogen, and that significant nitrogen removal occurs in the dark. Hence an unbalanced cellular uptake at low irradiance (and at depths with greater nitrate concentrations) may have permitted 
these cells to accumulate additional nitrogen. Fractionated samples also showed that only small $(<20 \mu \mathrm{m})$ cells had relatively low $\mathrm{C}: \mathrm{N}$ ratios at all depths, including those with low nutrient concentrations (Figure 6). Small cells appeared to be more efficient in assimilating nitrogen than larger cells, an observation corroborated by results of fractionated uptake experiments in the Barents Sea [Kristiansen et al., 1994].

Phytoplankton $\mathrm{C}: \mathrm{N}$ ratios that deviate from Redfield also may result from nutrient deficiency due to a decrease in organic nitrogen (protein) and an increase in lipid or carbohydrate storage [e.g., Antia et al., 1963; Sakshaug and HolmHansen, 1977]. During our study, the ratio of protein synthesis to low molecular weight metabolites and an increase in lipid synthesis in phytoplankton during June and July provided physiological evidence that both nitrate and silicate limitation occurred at more productive stations [R.E.H. Smith et al., 1997]. Although a continuous supply of nutrients was advected into the polynya, the initial surface nitrate concentrations of source water was only about $4 \mu M$ and therefore relatively low [Wallace et al., 1995; Kattner and Budéus, 1997]. As a result, nitrate limitation may have influenced phytoplankton $\mathrm{C}: \mathrm{N}$ ratios throughout the productive season.

Another important factor contributing to elevated $\mathrm{C}: \mathrm{N}$ ratios was the species composition of phytoplankton. Chaetoceros socialis, the bromass dominant species in productive areas, is a common bloom diatom species in northern waters and has a mucilaginous sheath [Drebes, 1974; Hasle and Fryxell, 1995]. It therefore would be expected to have a higher carbon content relative to nitrogen. In the polynya, small cells generally dominated in areas of high ice cover, while colonial and chain-forming diatoms $10-100 \mu \mathrm{m}$ in size dominated phytoplankton taxa in open water regions [Booth and Smith, 1997; Pesant et al., 1998]. On the basis of microscopic analyses and pigment data, detritus did not appear to significantly influence the particulate $\mathrm{C}: \mathrm{N}$ ratio [Daly, 1997]. $\mathrm{C}: \mathrm{N}$ ratios were elevated in larger size fractions owing to a lower nitrogen content, concomitant with an increase in fucoxanthin, a diatom accessory pigment, providing further evidence that diatoms were nutrient limited and had relatively high $\mathrm{C}: \mathrm{N}$ ratios.

4.1.3. Zooplankton lipid storage, fecal pellets, and DOM release. In Arctic regions, zooplankton biomass usually is dominated by copepods, which have a high lipid content. On the Greenland shelf the most common species of copepods included the herbivorous Calanus hyperboreus, $C$. glacialis, and C. finmarchicus and the omnivorous Metridia longa [Ashjian et al., 1995]. In most other marine systems, C:N ratios for zooplankton are lower than the ratios for particulate matter and therefore lower than the Redfield ratio. Arctic copepods, however, have higher $\mathrm{C}: \mathrm{N}$ ratios than copepods in lower latitudes, especially during summer when they store lipids for periods of low food availability [Bämstedt, 1986]. During our study, lipid content averaged between $51 \%$ and $60 \%$ of body weight in female $C$. hyperboreus, $36 \%$ and $46 \%$ in C. glacialis, and $30 \%$ and $32 \%$ in $M$. longa in different regions of the study area [Ashiian et al., 1995]. Thus C:N ratios greater than Redfield-Takahashi proportions are typical for the dominant zooplankton in northern high-latitude regions.
Zooplankton elemental ratios and physiology were influenced by elemental cycling by phytoplankton, and, in turn, zooplankton influenced the form, quantity, and location of carbon and nitrogen cycling between particulate and dissolved pools. Body and metabolic $\mathrm{C}: \mathrm{N}$ ratios of $C$. hyperboreus were indistinguishable from the ratio of particulate matter, implying a strong elemental coupling between phytoplankton and zooplankton. Carbon and nitrogen turnover rates in females relative to body carbon and nitrogen were in balance, and over short timescales the carbon and nitrogen content of available food largely explained the variation in respiration $(80 \%)$ and excretion $(60 \%)$ rates in females [Daly, 1995]. On average, one female copepod excreted more ammonium than was assimilated by phytoplankton in $1 \mathrm{~L}$ of seawater (Table 1). Owing to spatial variability in abundance and low excretion rates, however, copepods probably were not the main source of ammonium within the entire euphotic zone. Copepods were more effective as a control of phytoplankton standing stock (on average, $41 \%$ of primary production consumed) than in sustaining production via ammonium excretion ( $8 \%$ ) (Table 4). The primary source of ammonium may have been microheterotrophs, because bacterial activity was reduced [Ritzcu, 1997]. Alternatively, in situ ammonium uptake rates may have been lower than indicated by the empirically derived phytoplankton rates.

The molar C:N ratio (33.2) of copepod fecal pellets, which are a common component of sinking particulate matter, was substantially higher than the ratios for other measured parameters in our study. Our geometric mean ratio also was $33 \%$ higher ( $\mathrm{C}: \mathrm{N}=28.5$ by weight) than all previous reports of C:N ratios for copepod pellets from lower latitudes (e.g., $\mathrm{C}: \mathrm{N}=4.9$ to 19 by weight [Gerber and Gerber, 1979; Small et al., 1983; Honjo and Roman, 1978] for comparison, Redfield $\mathrm{C}: \mathrm{N}=5.9$ by weight). High $\mathrm{C}: \mathrm{N}$ ratios for copepod fecal pellets also were observed in the Chukchi and Beaufort Seas of the Arctic Ocean (K. Daly, unpublished data, 1996). Collective evidence suggests that the unusually high egestion ratio resulted from $C$. hyperboreus ingesting food with a relatively low nitrogen content, coupled with a higher assimilation efficiency for nitrogen than carbon. Although this process has been attributed to copepods in other systems, northern highlatitude copepods appear to have achieved a higher level, possibly because the food they ingest has a relatively higher carbon-to-nitrogen content, and because these copepods have sequestered lipids, they may not need to assimilate as much carbon to support metabolic demands as copepods at lower latitudes. The following data support this hypothesis. (1) Carbon and nitrogen content of available food largely explained the variations in carbon (54\%) and nitrogen (70\%) egestion rates [Daly, 1997]. (2) Female copepods were most abundant at depths near the chlorophyll maximum (upper $40 \mathrm{~m}$ ) [Ashjian et al., 1995], where phytoplankton were more likely to be nutrient deficient and therefore carbon rich. (3) C. hyperboreus most likely fed on diatoms, which were carbon rich, because abundances of ciliates and dinoflagellates were low [Barthel, 1988]. (4) C. hyperboreus is more efficient in ingesting food $>20 \mu \mathrm{m}$ in size [Huntley, 1981; Hansen et al., 1994]. Two abundant phytoplankton species, Fragilariopsis spp. and Thalassiosira spp., were $20-100 \mu \mathrm{m}$ in size (B. 
Booth, personal communication, 1995), the size fraction with a relatively low nitrogen content (Figure 5). Both of these species form chains, and the cells of $C$. socialis form colonies, making their effectıve size even larger. (5) In experiments, $C$. hyperboreus assimilated nitrogen more efficiently than carbon [Daly, 1997]. Ingested food need only have had a C:N ratio of 9 to account for the average ratio of fecal matter (Table 3 ).

The mass balance calculations for female $C$. hyperboreus suggested that a substantial portion of the carbon (32\%) and nitrogen $(83 \%)$ ingested ultimately was released as dissolved organic matter (Table 3 ). The DOC:DON ratio (3.5) released by copepods was lower than the Redfield ratio. These calculations appear to be reasonable because the estimated ingestion rates (equivalent to about $7 \%$ of body weight and $13 \%$ of body carbon and nitrogen per day) and the respiration and excretion rates are within the range reported for Arctic copepods [e.g., Barmstedt and Tande, 1985; Tande and Bàmstedt, 1985; Barthel, 1990]. Carbon and nitrogen egestion rates have not been previously determined for Arctic copepods, so there are no other studies for comparison. The net growth efficiency $K_{2}$ may be an overestimate for females, but a decrease in $K_{2}$ would increase DOC production. Conversely, if nitrogen "growth" occurred in proportion to body C:N (9.6), then the estimate of DON release would decrease to $67 \%$ of ingested nitrogen. Nevertheless, the mass balance estimates indicate that release rates could be substantial and that further laboratory and field experiments are warranted.

Our mass balance estimates for dissolved carbon production by female $C$. hyperboreus are similar to the highest rates measured in laboratory experiments, while our dissolved nitrogen estimates appear to be higher than other published rates. Female and stage V C. hyperboreus [Conover, 1966b] and C. pacificus [Copping and Lorenzen, 1980] were reported to have excreted $15 \%$ to $19 \%$ of the carbon ingested as DOC. More recently, Strom et al. [1997] reported that grazing C. pacificus females released $16 \%-30 \%$ of algal carbon as DOC. Part of the DOC released is in the form of nitrogenous compounds, such as urea and amino acids. Copepods are presumed to be primarily ammoniotelic, with ammonium excretion accounting for $47 \%$ to $86 \%$ of total nitrogen excreted [Le Borgne, 1986]. Both urea and amino acid excretion, however, appear to be variable and may be related to food quality [Bidigare, 1983]. Urea excretion in C. hyperboreus was $13 \%$ to $23 \%$ of ammonium excretion in the Barents Sea [Bamstedt, 1985] and 5\% to 13\% in the Canadian Arctic [Conover and Cota, 1985]. Given the extent of urea uptake by phytoplankton during this study, rates of urea excretion by the zooplankton community may have been similar to ammonium rates. Little is known about amino acid excretion in Arctic copepods, but $0 \%$ to $21 \%$ of total nitrogen excretion has been reported for zooplankton in other regions (reviewed by Bidigare [1983]).

Even given the uncertainties in the mass balance calculations, it appears that most of the ingested nitrogen was converted into dissolved organic matter, with possibly a small proportion into zooplankton biomass, whereas ingested carbon was allocated in the same proportion to both the particulate pool (i.e., zooplankton biomass and fecal pellets) and the dissolved organic pool. Hence elemental cycling by $C$. hyper- boreus formed carbon-rich particulate matter but resupplied inorganic and organic carbon and nitrogen to the dissolved pool at relatively low $\mathrm{C}: \mathrm{N}$ ratios. Because these herbivorous copepods did not vertically migrate during our study [Ashjian et al., 1995], all matter was excreted or egested in the surface layer. Although copepods egested a significant amount of carbon in fecal pellets (equivalent to $20 \%$ of the carbon flux from $50 \mathrm{~m}$ [Daly, 1997]), few copepod pellets were found in sediment traps moored near bottom [Bauerfeind et al., 1997]. It is unknown if the pellets were recycled in the surface layer or at intermediate depths, but most of the small omnivorous copepods that ingest fecal pellets tended to occur below $75 \mathrm{~m}$ in the polynya [Ashjian et al., 1995], which suggests that herbivore pellets may have sunk from the euphotic zone before being remineralized.

\subsection{New Production and Carbon Export}

The concept of new production assumes systerns are in steady state (i.e., annual timescale), but marine systems typically are sampled over much smaller timescales, confounding estimates of new production and comparison among regions [Platt et al. 1989, 1992]. In high-latitude systems, production and export occur primarily during summer. Integrated nitrate uptake during our study, averaged over 20 -day periods during summer 1993, indicated that production from nitrate uptake increased between May and early August, then decreased [ $W$. $O$. Smith et al., 1997]. Moored, near-bottom sediment traps (adjacent to the time series station) also documented two periods when particulate matter reached the seafloor, one after the ice melted in June and the second, equivalent to $40 \%$ to $70 \%$ of the annual flux, between August and October [Bauerfeind et al., 1997]. Hence mast of the annual flux of carbon from the euphotic zone occurred over a period of approximately 120 days, but with an increasing trend during most of that period.

The estimates of carbon-equivalent new production using different types of conversion factors only differed by $33 \%$ (Table 2). It is important to note that the estimates based on the $\mathrm{C}: \mathrm{N}$ ratio of phytoplankton uptake rates may not be directly comparable to the other estimates, because of the difference in timescales of in vitro measurements relative to that of bulk property measurements [Platt et al., 1989]. In our study, the $C: N$ uptake ratio that included urea, in addition to nitrate and ammonium, was similar to the $\mathrm{C}: \mathrm{N}$ ratio for particulate organic matter. Urea uptake also was found to be quantitatively important in Baffin Bay, the Bering Sea, and the Barents Sea [Harrison et al., 1985; Hansell and Goering, 1989; Kristiansen et al., 1994] and therefore may be an important source of nitrogen in Arctic marine systerns. The highest new production estimate resulted from the $\mathrm{DIC}: \mathrm{NO}_{3}$ consumption ratio. Banse [1994], however, cautioned against the use of this ratio because changes in $\mathrm{TCO}_{2}$ due to biological activity are the net effects of respiratory processes in autotrophs and heterotrophs, phytoplankton consumption, plus $\mathrm{CO}_{2}$ influx from the atmosphere. Although the copepod community did not appear to substantially affect the net changes in DIC during our study (Table 4), little is known about the influence of microheterotrophs.

Given that the $\mathrm{C}: \mathrm{N}$ ratio of particulate matter exceeded Redfield for most of the productive season (June - August), 
this ratio may be the most reasonable conversion factor to estimate the carbon-equivalent new production for this region. This estimate of new production $\left(35 \mathrm{mmol} \mathrm{C} \mathrm{m} \mathrm{m}^{-2}\right.$ ) also was similar to the estimate of particulate carbon flux (median, 36 mmol C m $\mathrm{m}^{-2}$ ) from the upper $50 \mathrm{~m}$ based on thorium 234 measurements [Cochran et al., 1995]. Both estimates are $25 \%$ higher than the Redfield estimate and are equivalent to $52 \%$ of the average daily integrated primary production during August. This percentage of export is substantially higher than the global average of $20 \%$ of primary production [Berger et $a l ., 1988]$. The $25 \%$ difference between estimates may not seem large given that the variability in measurements of nitrate uptake rates and thorium 234 flux was greater than the $33 \%$ difference among all new production estimates; however, if the Redfield-estimated new production represented a systematic bias and was applied globally, then the $25 \%$ error would be multiplicative.

There are few estimates of new production for the Arctic based on nitrate assimilation that can be directly compared; however, the daily rate of new production in the polynya was moderate when compared with estimates from a Phaeocystis

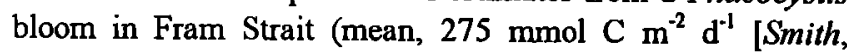
1993]). Arctic new production estimated using other methods varies over a wide range. For example, carbon export based on seasonal nitrate consumption (and a $\mathrm{C}: \mathrm{N}$ conversion factor of 6) over the Bering-Chukchi shelf was higher (200 $\mathrm{mmol} \mathrm{C}$ $\mathrm{m}^{-2} \mathrm{~d}^{-1}$ [Hansell et al., 1993]), and export based on sediment traps placed at the base of the surface mixed layer in the Barents Sea was lower ( 3.9 to $9.8 \mathrm{mmol} \mathrm{C} \mathrm{m}^{-2} \mathrm{~d}^{-1}$ [Wassman et al., 1994]). Daily new production in the polynya was 3 to 7 times greater than recent estimates for the upwelling region of the equatorial Pacific [Dugdale et al., 1992; Murray et al., 1994] or the oligotrophic eastern Atlantic [Lewis et al., 1986] but an order of magnitude lower than estimates from eastern boundary upwelling systems [Dugdale and Wilkerson, 1992]. Our rates also were lower than estimates for coastal Antarctic waters in the vicinity of a Phaeocystis bloom (103 mmol C $\mathrm{m}^{-2} \mathrm{~d}^{-1}$ [Smith and Dunbar, 1999]), but similar to the daily new production estimated for the Scotia-Weddell Sea marginal ice zone (27 mmol C m $\mathrm{m}^{-2} \mathrm{~d}^{-1}$ [Smith and Nelson, 1990]).

\section{Summary}

The results of our study indicate that biogeochemical processes on the Greenland coast did not operate within expected Redfield stoichiometry during most of the productive season and that the extent that carbon and nitrogen cycling was uncoupled may differ significantly from that in other regions. Although there presently is insufficient information about other systems, particularly with respect to dissolved organic pools, to test this hypothesis, several observations from this study support this conclusion. First, DOC concentrations and the C:N ratio of the dissolved organic pool was higher than those reported for lower or southern high-latitude systems but is consistent with other reports from Arctic regions, while the seasonal increase in DOC concentration was similar to that observed at lower latitudes. Second, the $C: N$ ratio of unfractionated particulate organic matter was elevated with respect to Redfield proportions throughout most of the productive season. The particulate matter ratio was a function of nutrient concentration, microplankton cell size, and species composition. Low initial nitrate concentrations in Arctic source water contributed to the pervasive nutrient limitation and elevated $\mathrm{C}: \mathrm{N}$ ratios of phytoplankton in the polynya. The dominant phytoplankton likely to form sinking particles were chainforming or colonial diatoms that were carbon rich, based on measurements of lipid synthesis and size-fraction data. The dominant diatom species, Chaetoceros socialis, also may have a mucilaginous sheath that would contribute to an elevated carbon content. Third, the dominant zooplankton in Arctic regions, herbivorous copepods, have a higher body $\mathrm{C}: \mathrm{N}$ ratio than zooplankton at lower latitudes, owing to lipid storage during summer. The $\mathrm{C}: \mathrm{N}$ ratios of fecal pellets produced by these copepods are the highest ever reported. If these large pellets sink out of the surface layer, then they would substantially influence the $\mathrm{C}: \mathrm{N}$ ratio of the particulate flux to deep water. In addition, copepods may release significant amounts of dissolved organic matter in the surface layer. Although these processes are not unique to northern high-latitude regions, the magnitudes of these processes interact to enhance the extent of uncoupling between carbon and nitrogen.

Overall, the particulate (i.e., particulate organic matter, copepods, and fecal pellets) and dissolved organic matter was more highly enriched in carbon relative to nitrogen, and microbial activity was relatively low compared with that in other marine systems. Mesozooplankton activities in the surface layer influenced the stoichiometry and material flow between particulate and dissolved pools in this system, primarily through grazing control of phytoplankton biomass, the egestion of fecal pellets deficient in nitrogen, and potentially through the production of substantial amounts of dissolved organic matter. Copepod-dissolved organic excretion, however, does not appear to account for the anomalous $\mathrm{C}: \mathrm{N}$ ratio of the dissolved pool, and the uncoupling of DOC and DON cannot be fully explained by the present results. Presumably, preferential recycling of nitrogen and low remineralization rates by microheterotrophs must influence this pool. If the transport of dissolved organic matter to deep water is substantial, it constitutes an additional sink for carbon and nitrogen not taken into account by the concept of new production. The variability in C:N ratios demonstrates the complexity of the influence of biological processes on geochemical fluxes, which may be ecosystem specific, and the influence of different timescales over which processes occur.

Acknowledgments. This research was supported by grants from the U.S. National Science Foundation (OPP-911378; OPP-9113818), the Swedish Institute, the Natural Sciences and Engineering Research Council of Canada, the Fonds FCAR of Québec, and the Fonds Institutionnel de Recherche, Université du Québec à Rimouski. We thank the officers and crew of the USCGC Polar Sea and FS Polarstern for assistance at sea and A. Close, C. Belzile, G. Bergeron, D. Guffy, S. Lessard, L. Monty, C. Neill, S. Pesant, S. Polk, R. Ramirez, A.-M. White, and $\mathrm{R}$. Wilke for technical assistance. We are especially grateful to $K$. Johnson for measurements of total carbon dioxide and to J. Campbell and $D$. Bunting for discussions on statistical analyses. $C$. Ashjian and S. Smith generously provided unpublished data that contributed to the interpretation of results. G. Kattner kindly provided facilites at the Alfred-Wegener-Institute for Polar and Marine Research for A. Skoog as a visiting scientist. Comments on an earlier draft of this manuscript by L. Codispoti and two anonymous reviewers were much appreciated. 


\section{References}

Anderson, L.G., K. Olsson, and A. Skoog, Distribution of dissolved inorganic and organic carbon in the Eurasian Basin of the Arctic Ocean, in The Polar Oceans and Their Role in Shaping the Global Environment, Geophys. Monogr. Ser., vol. 85, edited by O.M. Johannessen, R.D. Muench, and J.E. Overland, pp. 255-262, AGU, Washington, D.C., 1994.

Antia, N J., C.D McAllister, T.R. Parsons, K. Stephens, and J.D.H. Strickland, Further measurements of primary production using a large-volume plastic sphere, Limnol. Oceanogr., 8, 166-183, 1963.

Ashjian, C.J., S.L. Smith, and P.V.Z. Lane, The Northeast Water Polynya during summer 1992: Distribution and aspects of secondary production of copepods, J. Geophys. Res., 100, 4371-4388, 1995.

Båmstedt, U., Seasonal excretion rates of macrozooplankton from the Swedish west coast, Limnol. Oceanogr., 30, 607-617, 1985.

Båmstedt, U., Chemical composition and energy content, in The Biological Chemistry of Marine Copepods, edited by E.D.S. Corner and S C.M. O'Hara, pp. 1-58, Clarendon Press, Oxford, England, 1986.

Båmstedt, U., and K.S. Tande, Respiration and excretion rates of Calanus glacialis in arctic waters of the Barents Sea, Mar. Biol., 87, 259-266, 1985.

Båmstedt, U., K.S. Tande, and H. Nicolajsen, Ecological investigations on the zooplankton community of Balsfjorden, northern Norway: Physiological adaptations in Metridia longa (Copepoda) to the overwintering period, in Marine Biology of Polar Regions and Effects of Stress on Marine Organisms, edited by J.S. Gray and M.E. Christiansen, pp. 313-327, John Wiley, New York, 1985.

Banse, K., On the interpretation of data for the carbon-to-nitrogen ratio of phytoplankton, Limnol. Oceanogr., 19, 695-699, 1974.

Banse, K., Determining the carbon-to-chlorophyll ratio of natural phytoplankton, Mar Biol., 41, 199-212, 1977.

Banse, K., Uptake of inorganic carbon and nitrate by marine plankton and the Redfield ratio, Global Biogeochem. Cycles, 8, 81-84, 1994.

Barthel, K.-G., Feeding of three Calanus species on different phytoplankton assemblages in the Greenland Sea, Meeresforschung, 32. 92-106, 1988.

Barthel, K.-G., Relationships of food uptake and body components of Calanus finmarchicus, $C$. glacialis and $C$. hyperboreus to partıculate matter and water characteristics in Fram Strait, Polar Biol., $10,343-350,1990$

Bauerfeind, E., C Garrity, M. Krumbholz, R.O. Ramsier, and M. Voß, Seasonal variability of sediment trap collections in the Northeast Water Polynya, 2, Biochemical and microscopic composition of sedimenting matter, J. Mar. Syst., 10, 371-389, 1997.

Bedo, A.W , E.J.H. Head, R.J. Conover, E.P.W. Horne, and L.R. Harris, Physiological adaptations of an under-ice population of Pseudocalanus in Barrow Strait (N.W.T.) to increasing food supply in spring, Polar Blol., 10, 561-570, 1990.

Beers, J.R, Studies on the chemical composition of the major zooplankton groups in the Sargasso Sea off Bermuda, Limnol. Oceanogr., 11, 520-528, 1966.

Benner, R., J.D. Pakulski, M. McCarthy, J.I. Hedges, and P.G. Hatcher, Bulk chemical characteristics of dissolved organic matter in the ocean, Science, 255, 1561-1564, 1992.

Berger, W.H., K. Fischer, C. Lai, and G. Wu, Ocean carbon flux: Global maps of primary production and export production, in Biogeochemical Cycling and Fluxes Between the Deep Euphotic Zone and other Oceanic Realms, Res. Rep $88-1$, edited by C.R. Agegian, pp. 131-176, Undersea Res. Program, Natl. Oceanic and Atmos. Admin, Silver Spring, Md, 1988.

Bidigare, R R., Nitrogen excretion by marine zooplankton, in Nitrogen in the Marine Environment, edited by E.J. Carpenter and D.G. Capone, pp. 385-409, Academic, San Diego, Calif., 1983.

Booth, B.C., and W O. Smith Jr., Autotrophic flagellates and diatoms in the Northeast Water Polynya, Greenland: Summer 1993, J. Mar. Syst , 10, 241-261, 1997.

Borsheim, K Y., and S M. Myklestad, Dynamics of DOC in the Norwegian Sea inferred from monthly profiles collected during 3 years at $66^{\circ} \mathrm{N}, 2^{\circ} \mathrm{E}$, Deep Sea Res., Part 1, 44, 593-601, 1997.

Budéus, $G$., and W. Schneider, On the hydrography of the Northeast Water Polynya, $J$ Geophys. Res., 100, 4287-4299, 1995.
Campbell, J.W., and T. Aarup, New production in the North Atlantic derived from seasonal patterns of surface chlorophyll, Deep Sea Res., Part A. 39, 1669-1694, 1992.

Carlson, C.A., and H.W. Ducklow, Dissolved organic carbon in the upper ocean of the central equatorial Pacific Ocean, 1992: Daily and finescale vertical variations, Deep Sea Res., Part II, 42, 639$656,1995$.

Carlson, C.A., H.W. Ducklow, and A.F. Michaels, Annual flux of dissolved organic carbon from the euphotic zone in the northwestern Sargasso Sea, Nature, 371, 405-408, 1994.

Carlson, C.A., H.W. Ducklow, D.A. Hansell, and W.O. Smith Jr., Organic carbon partitioning during spring phytoplankton blooms in the Ross Sea polynya and the Sargasso Sea, Limnol. Oceanogr., 43, 375-386, 1998.

Chen, C.-T.A., C.-M Lin, B.-T. Huang, and L.-F. Chang, Stoichiometry of carbon, hydrogen, nitrogen, sulfur and oxygen in the particulate matter of the western North Pacific marginal seas, Mar. Chem, 54, 179-190, 1996.

Claustre, H., S.A. Poulet, R. Williams, F. Ben-Mlih, V. MartinJézéquel, and J.-C. Marty, Relationship between the qualitative nature of particles and copepod faeces in the Irish Sea, Mar. Chem, 40, 231-248, 1992.

Cochran, J.K., C. Barnes, D. Achman, and D. Hirschberg, Thorium234/Uranium-238 disequilibrium as an indicator of scavenging rates and particulate organic fluxes in the Northeast Water Polynya, J. Geophys. Res., 100, 4399-4410, 1995.

Conover, R.J., Food relations and nutrition of zooplankton, Proc. Symp. Exper. Mar. Ecol., Univ. RI, 2, 81-91, 1964.

Conover, R. J., Assimilation of organic matter by zooplankton, Limnol. Oceanogr., 11,338-345, 1966a.

Conover, R.J., Feeding on large particles by Calanus hyperboreus (Kroyer), in Some Contemporary Studies in Marine Science, edited by H. Barnes, pp. 187-194, Allen and Unwin, Winchester, Mass., 1966b.

Conover, R.J., and G.F. Cota, Balance experiments with arctic zooplankton, in Marme Biology of Polar Regions and Effects of Stress on Marine Organisms, edited by J.S. Gray and M.E. Christiansen, pp. 217-236, John Wiley, New York, 1985.

Conover, R.J., and M. Huntley, Copepods in ice-covered seas -- Distribution, adaptations to seasonally limited food, metabolism, growth patterns and life cycle strategies in polar seas, J. Mar. Syst., $2,1-41,1991$.

Copin-Montegut, C., and G. Copin-Montegut, Stoichiometry of carbon, nitrogen, and phosphorus in marine particulate matter, Deep Sea Res., Part A, 30, 31-46, 1983.

Copping, A.E., and C.J. Lorenzen, Carbon budget of a marine phytoplankton-herbivore system with carbon-14 as a tracer, Limmol. Oceanogr., 25, 873-882, 1980.

Corkett, C.J., and I.A. McLaren, The biology of Pseudocalanus, $A d v$. Mar. Biol., 15, 1-231, 1978.

Daly, K.L., The influence of zooplankton on biogeochemical fluxes and stoichiometry in an Arctic marine system, Ph.D. dissertation, 183 pp., Univ. of Tenn., Knoxville, 1995.

Daly, K.L., Flux of particulate matter through copepods in the Northeast Water Polynya, J. Mar. Syst., 10, 319-42, 1997.

Drebes, G., Marines Phytoplankton. Eine Auswahl der Helgoländer Planktonalgen (Dratomeen, Peridineen), 186 pp., Georg Thieme, Stuttgart, Germany, 1974.

Dugdale, R.C., and J.J. Goering, Uptake of new and regenerated forms of nitrogen in primary productivity, Limnol. Oceanogr., 12, 196-206, 1967.

Dugdale, R.C., and F.P. Wilkerson, Nutrient limitation of new production in the sea, in Primary Productivity and Biogeochemical Cycles in the Sea, edited by P.G. Falkowski and A.D. Woodhead, pp. 107-122, Plenum, New York, 1992.

Dugdale, R.C., F.P. Wilkerson, R.T. Barber, and F.P. Chavez, Estimating new production in the equatorial Pacific Ocean at $150^{\circ} \mathrm{W}, J$. Geophys. Res., 97, 681-686, 1992.

Eilertsen, H.C., K.S. Tande, and J.P. Taasen, Vertical distributions of primary production and grazing by Calanus glacialis Jaschnov and C. hyperboreus Kroyer in Arctic Waters (Barents Sea), Polar Biol., 9, 253-260, 1989.

Eppley, R.W., and B J. Peterson, Particulate organic matter flux and planktonic new production in the deep ocean, Nature, 282, 677$680,1979$. 
Gerber, R.P., and M.B. Gerber, Ingestion of natural particulate matter and subsequent assimilation, respiration, and growth by tropical lagoon zooplankton, Mar. Biol., 52, 33-43, 1979.

Hansell, D.A., and J.J. Goering, A method for estimating uptake and production rates for urea in seawater using ${ }^{14} \mathrm{C}$ and ${ }^{15} \mathrm{~N}$-urea, Can. J. Fish. Aquat. Scl , 46, 198-202, 1989.

Hansell, D.A., T.E. Whitledge, and J.J. Goering, Patterns of nitrate utilization and new production over the Bering-Chukchi shelf Cont. Shelf Res., 13, 601-627, 1993.

Hansen, B., P. Verity, T. Falkenhaug, K.S. Tande, and F. Norrbin, On the trophic fate of Phaeocystis pouchetii (Harriot). V. Trophic relationships between Phaeocystis and zooplankton: An assessment of methods and size dependence, $J$. Plankton Res., 16, 487$511,1994$.

Haq, S.M., Nutritional physiology of Metridia lucens and $M$. longa from the Gulf of Maine, Limnol. Oceanogr., 12, 40-51, 1967.

Harrison, W.G., E.J. Head, R.J. Conover, A.R. Longhurst, and D.D. Sameoto, The distribution and metabolism of urea in the eastern Canadian Arctic, Deep Sea Res., Part A, 32, 23-42, 1985.

Hasle, G.R., and G.A. Fryxell, Taxonomy of diatoms, in Manual on Harmful Marine Microalgae, edited by G.M. Hallegraeff, D.M. Anderson, and A.D. Cembella, pp. 339-364, IOC/UNESCO, 1995.

Honjo, S., and M.R. Roman, Marine copepod fecal pellets: Production, preservation and sedimentation, J. Mar. Res., 36, 45-57, 1978.

Huntley, M., Nonselective, nonsaturated feeding by three calanoid copepod species in the Labrador Sea, Limnol. Oceanogr., 26, 831842,1981

lkeda, T., Metabolic rates of epipelagic marine zooplankton as a function of body mass and temperature, Mar. Biol., 85, 1-11, 1985.

Ikeda, T., and H.R. Skjoldal, Metabolism and elemental composition of zooplankton from the Barents Sea during early Arctic summer, Mar. Biol., 100, 173-183, 1989.

Jahnke, R.A., Ocean flux studies: A status report, Rev. Geophys., 28, 381-398. 1990.

Johnson, K.M., K.D. Wills, D.B. Butler, W.K. Johnson, and C.S Wong, Coulometric total carbon dioxide analysis for marine studies: Maximizing the performance of an automated gas extraction system and coulometric detector, Mar. Chem., 44, 167-187, 1993.

Johnson, M., and H.J. Niebauer, The 1992 summer circulation in the Northeast Water Polynya from acoustic Doppler current profiler measurements, J. Geophys. Res., 100, 4301-4308, 1995.

Kattner, G., and G. Budéus, Nutrient status of the Northeast Water Polynya, J. Mar. Syst., 10, 185-197, 1997.

Kepkay, P.E., S.E.H Niven, and T.G. Milligan, Low molecular weight and colloidal DOC production during a phytoplankton bloom, Mar. Ecol. Prog. Ser., 100, 233-244, 1993.

Koroleff, F., Determination of urea, in Methods of Seawater Analysis, edited by K. Grasshoff, M. Ehrhardt, and K. Kremling, pp. 158162, Verlag Chemı, Weinheim, Germany, 1983.

Kristiansen, S., T. Farbrot, and P.A. Wheeler, Nitrogen cycling in the Barents Sea - Seasonal dynamics of new and regenerated production in the marginal ice zone, Limnol. Oceanogr., 39, 1630-1642, 1994.

Lara, R.J., U. Hubberten, and G Kattner, Contribution of humic substances to the dissolved pool in the Greenland Sea, Mar. Chem., 4I, 327-336, 1993.

LeBorgne, R., The release of soluble end products of metabolism, in The Biological Chemistry of Marine Copepods, edited by E.D.S. Corner and S.C.M. O'Hara, pp. 109-164, Clarendon Press, Oxford, England, 1986.

Lewis, M.R., W.G. Harrison, N.S. Oakey, D. Herbert, and T. Platt, Vertical nitrate fluxes in the oligotrophic ocean, Science, 234, 870873, 1986.

Longhurst, A.R., Role of the marine biota in the global carbon cycle, Limnol. Oceanogr., 36, 1507-1526, 1991.

Mayzaud, P., Respiration and nitrogen excretion of zooplankton, IV, The influence of starvation on the metabolism and the biochemical composition of some species, Mar. Biol., 37, 47-58, 1976.

McArdle, B.H., The structural relationship: Regression in biology, Can. J. Zoology, 66, 2329-2339, 1988.

Murray, J.W., R.T. Barber, M.R. Roman, M.P. Bacon, and R.A. Feely, Physical and biological controls on carbon cycling in the Equatorial Pacific, Science, 266, 58-65, 1994.

Naijar, R.G., J.L. Sarmiento, and J.R. Toggweiler, Downward trans- port and fate of organic matter in the ocean: Simulations with a general ocean circulation model, Global Biogeochem. Cycles, 6, 45-76, 1992.

NEWATER Steering Committee and Principal Investigators, Northeast Water Polynya: Polar Sea cruise results, Eos Trans. AGU, 74, 185, 195-196, 1993.

Pesant, S., et al., Pathways of carbon cycling in the euphotic zone: The fate of large-sized phytoplankton in the Northeast Water Polynya, J. Plankton Res., 20, 1267-1291, 1998.

Platt, T., W.G. Harrison, M.R. Lewis, W.K.W. Li, S. Sathyendranath, R.E. Smith, and A.F. Vézina, Biological production of the oceans: The case for a consensus, Mar. Ecol. Prog. Ser., 52, 77-88, 1989.

Platt, T., P. Jauhari, and S. Sathyendranath, The importance and measurement of new production, in Primary Productivity and Bio. geochemical Cycles in the Sea, edited by P.G. Falkowski and A.D. Woodhead, pp. 273-284, Plenum, New York, 1992.

Poulet, S.A., Comparison between five coexisting species of marine copepods feeding on naturally occurring particulate matter, Limnol. Oceanogr., 23, 1126-1143, 1978.

Redfield, A.C., B.H. Ketchum, and F.A. Richards, The influence of orgari'sms on the composition of seawater, in The Sea. Ideas and Observations on Progress in the Study of the Seas, edited by M.N. Hill, pp. 26-77, John Wiley, New York, 1963.

Ricker, W.E., Linear regressions in fishery research, J. Fish. Res. Board Can., 30, 409-434, 1973.

Ritzau, W., Pelagic microbial activity in the Northeast Water Polynya, summer 1992, Polar Biol., 17, 259-267, 1997.

Sakshaug, E., and O. Holm-Hansen, Chemical composition of Skeletonema costatum (Grev.) Cleve and Pavlova (Monochrysis) lutheri (Droop) Green as a function of nitrate-, phosphate-, and ironlimited growth, J. Exp. Mar. Biol. Ecol, 29, 1-34, 1977.

Sambrotto, R.N., G. Savidge, C. Robinson, P. Boyd, T. Takahashi, D.M. Karl, C. Langdon, D. Chipman, J. Marra, and L. Codispoti, Elevated consumption of carbon relative to nitrogen in the surface ocean, Nature, 363, 248-250, 1993.

Shaffer, G., Biogeochemical cycling in the global ocean, 2 , New production, Redfield ratios, and remineralization in the organic pump, J. Geophys. Res., 101, 3723-3745, 1996.

Siegenthaler, U., and J.L. Sarmiento, Atmospheric carbon dioxide and the ocean, Nature, 365, 119-125, 1993.

Six, K.D., and E. Maier-Reimer, Effects of plankton dynamics on seasonal carbon fluxes in an ocean general circulation model, Global Biogeochem. Cycles, 10, 559-583, 1996.

Small, L.F., S.W. Fowler, S.A. Moore, and J. LaRosa, Dissolved and fecal pellet carbon and nitrogen release by zooplankton in tropical waters, Deep Sea Res., Pari A, 30, 1199-1220, 1983.

Smith, R. E. H., M. Gosselin, G. Kattner, L. Legendre, and S. Pesant, Biosynthesis of macromolecular and lipid classes by phytoplankton in the Northeast Water Polynya, Mar. Ecol. Prog. Ser., 147, 231242, 1997.

Smith, S.L., Copepods in Fram Strait in summer: Distribution, feeding and metabolism, J. Mar. Res., 46, 145-181, 1988.

Smith, W.O., Jr., Nitrogen uptake and new production in the Greenland Sea: the spring Phaeocystis bloom, J. Geophys. Res., 98, 4681-4688, 1993.

Smith, W.O., Jr., Primary productivity and new production in the Northeast Water (Greenland) Polynya during summer 1992, $J$. Geophys. Res, 100, 4357-4370, 1995.

Smith, W.O., Jr., and R. Dunbar, The relationship between new production and vertical flux on the Ross Sea continental shelf, $J$. Mar. Syst., 17, 445-457, in press, 1999.

Smith, W.O., Jr., and W.G. Harrison, New production in polar regions: The role of environmental controls, Deep Sea Res., Part A. 38, 1463-1479, 1991.

Smith, W.O., Jr., and D.M. Nelson, Phytoplankton growth and new production in the Weddell Sea marginal ice zone during austral spring and autumn, Limnol. Oceanogr., 35, 809-821, 1990.

Smith, W.O., Jr., L.A. Codispoti, D.M. Nelson, T. Manley, E.J. Buskey, H.J. Niebauer, and G.F. Cota, Importance of Phaeocystis blooms in the high-latitude ocean carbon cycle, Nature, 352, 514516,1991

Smith, W.O., Jr., M. Gosselin, L. Legendre, D.W.R. Wallace, K.L. Daly, and G. Kattner, New production in the Northeast Water Polynya: 1993, J. Mar. Syst., 10, 199-209, 1997.

Strom, S.L., R. Benner, S. Ziegler, and M.J. Dagg, Plankton grazers 
are a potentially important source of marine dissolved organic carbon, Limnol. Oceanogr., 42, 1364-1374, 1997.

Takahashi, T., W.S. Broecker, and S. Langer, Redfield ratio based on chemical data from isopycnal surfaces, J. Geophys. Res., 90, 6907$6924,1985$.

Tande, K.S., The effect of temperature on metabolic rates of different life stages of Calanus glacialis in the Barents Sea, Polar Biol., 8 , $457-461,1988$.

Tande, K.S., and U. Båmstedt, Grazing rates of the copepods Calanus glacialis and $C$. finmarchicus in Arctic waters of the Barents Sea, Mar. Biol., 87, 251-258, 1985.

Toggweiler, J.R., Carbon overconsumption, Nature, 363, 210-211, 1993.

Wallace, D.W.R., P.J. Minnett, and T.S. Hopkins, Nutrients, oxygen, and inferred new production in the Northeast Water Polynya, 1992, J. Geophys. Res., 100, 4323-4340, 1995.

Walsh, J.J., et al., Carbon and nitrogen cycling within the Bering/Chukchi seas: source regions for organic matter effecting AOU demands of the Arctic Ocean, Prog. Oceanogr., 22, 277-359, 1989.

Wassman, P., R. Martinez, and M. Vernet, Respiration and biochemical composition of sedimenting organic matter during summer in the Barents Sea, Cont. Shelf Res., 14, 79-90, 1994.

Wheeler, P.A., M. Gosselin, E. Sherr, D. Thibault, D.L. Kirchman, R. Benner, and T.E. Whitledge, Active cycling of organic carbon in the central Arctic Ocean, Nalure, 380, 697-699, 1996.

Wheeler, P.A., J.M. Watkins, and R.L. Hansing, Nutrients, organic carbon and organic nitrogen in the upper water column of the Arctic Ocean: Implications for the sources of dissolved organic carbon, Deep Sea Res., Part II, 44, 1571-1592, 1997.

Williams, P.J. leB., Evidence for the seasonal accumulation of carbonrich dissolved organic material, its scale in comparison with changes in particulate material and the consequential effect on net C/N assimilation ratios, Mar. Chem., 51, 17-29, 1995.
Williams, P.M., and E.R.M. Druffel, Dissolved organic matter in the ocean: Comments on a controversy, Oceanography, 1, 14-17, 1988.

Yager, P.L., The microbial fate of carbon in high latitude seas: Impact of the microbial loop on oceanic uptake of $\mathrm{CO}_{2}$, Ph.D. dissertation, 174 pp., Univ. of Wash., Seattle, 1996.

Yager, P.L., D.W.R. Wallace, K.M. Johnson, W.O. Smith Jr., P.J. Minnett, and J.W. Deming, The Northeast Water Polynya as an atmospheric $\mathrm{CO}_{2}$ sink: A seasonal rectification hypothesis, $J$. Geophys. Res., IDO, 4389-4398, 1995.

Zar, J.H., Biostatistical Analysis, 718 pp., Prentice-Hall, Englewood Cliffs, N.J., 1984.

K.L. Daly (corresponding author), Division of Ocean Sciences, National Science Foundation, 4201 Wilson Blvd., Room 725, Arlington, VA 22230 (kdaly@nsf.gov).

E. Falk, Geophysical Institute, University of Bergen, Bergen, Norway

M. Gosselin, Départment d'Océanographie, Université du Québec à Rimouski, Rimouski, Québec, Canada G5L 3A1.

R. Lara, Zentrum für Marine Tropenokolgie, Fahrenheitstr. I,

D-28359 Bremen, Germany.

A. Skoog, Department of Marine Science, University of Connecticut, Groton, CT 06340.

W.O. Smith Jr., Virginia Institute of Marine Science, Gloucester Point, VA 23062.

D.W.R. Wallace, Institut für Meereskunde, Universität Kiel, D-24105 Kiel, Germany.

P.L. Yager, Department of Marine Science, University of Georgia, Athens, GA 30602.

(Received April 3, 1998; revised October 22, 1998; accepted November 9,1998 .) 